\title{
Urbs e civitas: A Formação dos espaços e territórios urbanos nas Minas setecentistas'
}

\begin{abstract}
Claudia Damasceno Fonseca ${ }^{2}$
RESUMO: $\bigcirc$ presente artigo procura situar a evolução das abordagens acerca da cidade colonial mineira dentro da perspectiva mais ampla dos estudos sobre o urbanismo colonial português. A análise privilegia os trabalhos que, em vez de se aterem aos aspectos ligados à estética urbana, procuraram relacioná-los às questões fundiárias e à constituição das redes e hierarquias urbanas.

PALAVRAS-ChaVE: Minas Gerais. Urbanização. Período colonial. Redes urbanas. Câmaras municipais. Morfologia urbana.

ABSTRACT: This article seeks to situate the evolution of approaches to the study of the colonial towns of Minas Gerais placing them in the broader perspective of studies on the Portuguese colonial urbanism. Instead of restricting our approach to questions of urban aesthetics, the analysis focuses on the works that tried to relate these questions to aspects of land ownership and to the establishment of networks and urban hierarchies.

KEYWORDS: Minas Gerais. Mining towns. Colonial cities. Urban networks. Municipal councils. Urban morphology.
\end{abstract}

caráter predominantemente "urbano" do povoamento das Minas setecentistas foi sempre considerado pela historiografia como uma das principais particularidades que distinguem esta capitania das outras regiões da América portuguesa $^{3}$. No entanto, raramente as cidades foram abordadas como um objeto específico de pesquisa pelos especialistas da história colonial mineira. Na maior parte dos casos, elas serviram somente como delimitação espacial cômoda para análises de demografia histórica ou como pano de fundo para estudos de história política, social ou econômica. Ademais, como os estudos "mineirianos" privilegiaram, durante muito tempo, o período em que se verificou o crescimento e apogeu da produção aurífera e diamantina, permaneceram na sombra as

\begin{abstract}
1. Este artigo reúne alguns dos principais temas tratados, em 2001, na nossa tese de doutorado em História, defendida na École des Hautes Études en Sciences Sociales de Paris - para a versão da tese em língua portuguesa, ver Cláudia Damasceno Fonseca (2011). Também foram aqui incluídas análises historiográficas presentes em comunicações (algumas delas inéditas) apresentadas em colóquios e seminários realizados na França e em Portugal entre 1996 e 2010.

2. Docente da Université Sorbonne Nouvelle, Paris 3 , e pesquisadora do CREDA (Centre de Recherches et de Documentation des Amériques). $<$ E-mail: claudia. damasceno@wanadoo.fr>.
\end{abstract}

3. Cf. Caio Boschi (1994a, p. 63). 
4. Como se sabe, nesta época reconheceu-se a existência de um "estilo" local, que foi chamado de "Barroco Mineiro", embora nem sempre tal classificação se mostrasse pertinente. Como bem notou Myriam Ribeiro de Oliveira, ainda hoje persiste uma tendência de associar-se essa designação não só aos partidos arquitetônicos e elementos ornamentais influenciados pelo barroco tardio, mas também àqueles identificados com o Rococó (inclusive a produção do Aleijadinho). Cf. Myriam Ribeiro de Andrade Oliveira (2003, p. 101-105).

5.Ver Paulo Santos (1968).

6. Num texto recente, Renata Malcher de Araujo lembrou que, já em 1959, dois autores - Tito Lívio Ferreira e Manuel Rodrigues Ferreira, no capítulo Urbanismo no Brasil Província, em História da Civilização Brasileira - haviam se apoiado nas cartas régias de fundação de vilas (publicadas na década anterior por Paulo Thedim Barreto) para reavaliar "as leituras negadoras do urbanismo colonial"; cf. Renata Malcher de Araujo (2010, p. 39).

7. Como observado no interessante texto de Giovanna Rosso del Brenna (1982)

8. No final da década de 1970, a norte-americana Roberta Marx Delson afirmava que, dentre os trabalhos que contribuíram para criar e perpetuar "the myth of the unplanned Brazilian town", as interpretações contidas na obra Raízes do Brasil teriam sido as "menos inspiradoras, e as mais prejudiciais ao desenvolvimento dos estudos sobre as origens e a evolução das cidades brasileiras"; cf. Roberta Marx Delson (1979, p. 2).

9.Cf. Paulo Santos (1968, p.6). povoações que surgiram somente na segunda metade do século XVIII e que estiveram ligadas a outras atividades econômicas (exceção feita à produção dos historiadores e eruditos locais). Quanto aos historiadores da arte, inicialmente se dedicaram sobretudo ao estudo da arquitetura e arte sacras - sobretudo ao inventário e à descrição dos exemplares que foram classificados como "monumentos históricos" e tombados a partir do final da década de 19304.

Já a partir das décadas de 1950 e 1960, renovaram-se abordagens tratando das fundações urbanas coloniais, e alguns estudiosos dedicaram uma atenção especial às cidades mineiras. Em Formação de cidades no Brasil colonial, o arquiteto Paulo Ferreira Santos identificou as especificidades das implantações lusas, sem no entanto depreciá-las em relação às cidades hispanoamericanas, como haviam feito muitos de seus predecessores ${ }^{5}$. Segundo Santos, a diferença principal entre os dois métodos de urbanização seria a ausência de leis rígidas e específicas nas fundações realizadas na América pelos portugueses, pois estes últimos eram seres bem mais pragmáticos que seus vizinhos de Castela. Ao invés de preconizar uma "traça" a ser indefinidamente repetida, a Coroa portuguesa preferia transmitir apenas recomendações gerais aos governadores ou aos engenheiros militares - nomeadamente através das "cartas régias"b de fundação de vilas - que, assim, tinham liberdade para decidir caso a caso; o traçado das ruas deveria ser tão regular e retilíneo quanto possível, mas sem corresponder a um padrão pré-concebido. Ao mesmo tempo em que demonstrou a racionalidade e a lógica deste método, Paulo F. Santos - visivelmente influenciado pela leitura de Camillo Sitte, citado em seu texto - questionou uma ideia que estava implícita nos escritos de seus predecessores, especialmente no célebre texto de Sérgio Buarque de Holanda: a "superioridade intrínseca" dos traçados geométricos ${ }^{7}$.

Ao contrário de autores como Roberta Marx Delson ${ }^{8}$ - que mencionaremos adiante -, Santos eximiu-se de criticar abertamente as "palavras candentes" utilizadas pelo mestre Holanda, mas não deixou de observar que:

É difícil conciliar esse retrato com a ideia de havermos guindado essas mesmas cidades portuguesas do Brasil - Ouro Preto, São João del Rei, Mariana, Diamantina, Serro, Tiradentes, Parati, Goiás Velho, Salvador, Alcântara, etc. - em parte ou no todo, à categoria de monumentos nacionais [...]. Tais cidades são muito mais significativas do que a maioria das regulares e retilíneas que construímos depois da independência [...]. É que, naquela aparente desordem que leva a admitir, como o fez o eminente historiador patrício, a inexistência de um traçado prévio ou de uma ideia diretriz, existem uma coerência orgânica, uma correlação formal e uma unidade de espírito que the dão genuidade. Genuidade como expressão espontânea e sincera de todo um sistema de vida, e que tanta falta faz à cidade regular, traçada em rígido tabuleiro de xadrez. Esta, dado o "processus" mesmo de sua criação, há de ser, necessariamente, produto de uma ideia preconcebida com que o projetista pretende, não raro artificiosamente, ordenar, disciplinar, modelar a vida que nela vai ter lugar?.

De fato, a visão positiva da cidade mineira que emerge desse e de outros textos do período não advinha somente do avanço dos estudos sobre a urbanização colonial e a "urbanística portuguesa" - iniciados em Portugal por Luís 
da Silveira e Mário Chicó ${ }^{10}$ e, no Brasil, principalmente por Paulo Santos e Nestor Goulart Reis Filho ${ }^{11}$-, mas era também resultado evidente do processo de valorização e de "patrimonialização" das paisagens urbanas coloniais brasileiras, inaugurado nas décadas de 1920-1930. A partir de então, diversos artistas e intelectuais brasileiros começaram a mostrar-se sensíveis ao caráter "original", "genuíno" e "pitoresco" das povoações de Minas - características estas que, no início do século XIX, já haviam sido identificadas por viajantes estrangeiros como A. de Saint-Hilaire, mas, naturalmente, dentro de uma outra perspectiva ${ }^{12}$.

Além desse aspecto patrimonial, a apologia dos traçados "irregulares" feita por Santos deve ser relacionada à uma leitura organicista da cidade. Como se sabe, as analogias entre as implantações urbanas e os organismos vivos, que já eram eram imagens bastante difundidas na Europa do século XVIII ${ }^{13}$ e também no Novo Mundo, ${ }^{14}$ tornaram-se, no século seguinte, modelos explicativos da origem e do desenvolvimento das cidades, nomeadamente com os trabalhos de Patrick Geddes. No início do século XX, essa abordagem também foi adotada pelo erudito francês Marcel Poëte e, mais tarde, pelo norte-americano Lewis Munford (entre outros) ${ }^{15}$. No que toca especificamente ao mundo lusófono, na década de 1950 o português Luís da Silveira também afirmara que a "cidade orgânica portuguesa", com suas características "medievais", tendia para a "cidade perfeita", ou seja, aquela em que "cada elemento exerce uma função natural", enquanto que as cidades em damero demonstravam em geral "uma incompreensão do conceito da cidade como um organismo vivo, funcional e intelectualmente ativo, e sujeito aos princípios gerais da biologia e da sociologia"16.

Tal visão se encontra claramente expressa também nos importantes trabalhos de Sylvio de Vasconcellos - nos quais Paulo Santos certamente se inspirou, embora já efetuasse suas próprias pesquisas sobre a arquitetura e as cidades mineiras desde o início da década de 1950 ${ }^{17}$. Vasconcellos foi o primeiro a se interessar verdadeiramente pela arquitetura vernacular de Minas, bem como pelo estudo da gênese e morfologia urbana das povoações mineiras, descritas por vezes como "organismos vivos". Como Santos, o autor identificou as qualidades estéticas dos traçados não retilíneos, salientando que, na zona mineradora, tais qualidades eram acentuadas pela topografia acidentada. Segundo o arquiteto mineiro, a implantação das igrejas matrizes e das múltiplas igrejas e capelas das irmandades em largos ou em outeiros a cavaleiro das vias públicas produz belos efeitos cênicos e harmoniza-se com a paisagem natural:

A configuração espontânea e longilínea dá às povoações uma configuração mais orgânica, uma adaptação maior às condições do terreno e um agenciamento natural bastante diverso do racional partido preconizado pelas "Leis das Índias". O traçado fica mais dinâmico e, frequentemente, permite arranjos plásticos que funcionam como cenários, em perfeita harmonia com a paisagem circundante. O povoado cresce como the convém, espicha e encolhe conforme seu estágio de desenvolvimento, ameniza os aclives com traçados coleantes, absorve os terrenos mais favoráveis e rejeita os impróprios, participando da vida de seus habi-
10.Ver Mário Chicó (1956); Luís Silveira (1956).

11. Ver Nestor Goulart Reis Filho (1968). Não se deve esquecer, no entanto, que antes do trabalho de Reis Filho foram publicados os importantes estudos dos geográfos franceses Pierre Monbeig (1951) e Pierre Deffontaines (1938), bem como a série de artigos do geógrafo brasileiro Aroldo de Azevedo (1957a, 1957b, 1957c)

12. Ver Cláudia Damasceno Fonseca (2008).

13. Cf. Marcel Roncayolo et al. (1979, p. 111); e Bernard Lepetit (1988, p. 96)

14. Ver Cláudia Damasceno Fonseca (2003a).

15. Cf. Marcel Roncayolo e Thierry Pacquot (1992, p. 155-173).

16. Luís Silveira (1956), apud Roberta Marx Delson (1979, p. 3).

17.Ver Paulo Santos (1951). 
18. Cf. Sylvio de Vasconcellos (1959a, p. 5).

19. Idem, 1957.

20. Ver Caio Boschi (1986, 1994); Sérgio Da Mata (2002); e também Cláudia Damasceno Fonseca (2003, cap. 2 e 7).

21. Ver Beatriz Piccolotto Siqueira Bueno (2001); e Renata Malcher de Araujo (1998, 2000).

22. Ver Cláudia Damasceno Fonseca (2003a).

23. Ver Maria Fernanda Derntl (2010). No que toca a Minas Gerais, outros autores têm-se interessado, nos últimos anos, pelo estudo diacrônico da rede urbana mineira; ver Fernanda Borges de Moraes (2010).

24. Ver, entre outros, Maria Isabel Chrysostomo (2010).

25. Cf. Caio Boschi (1994a, p. 64-67). tantes como uma entidade também viva e livre das contenções determinadas por regras fixas ou tentativas de racionalização divorciadas da realidade ${ }^{18}$.

Mais adiante retomaremos as análises de Sylvio de Vaconcellos; por ora, observemos apenas que as considerações de ordem formal e estética presentes nos seus estudos, ainda que importantes, não constituem, a nosso ver, suas principais contribuições. Outros aspectos da sua obra apresentam maior relevância para o entendimento do processo de gênese da paisagem urbana mineira: a identificação do papel social das confrarias, a relação estabelecida entre a multiplicação destas últimas e o desenvolvimento (ou decadência) das matrizes e dos povoados que as abrigavam, entre outros ${ }^{19}$. Tais insights chamaram a atenção de estudiosos da história social e religiosa mineira que, por seu turno, também contribuíram para um melhor conhecimento da história dos núcleos e da hierarquia urbana da capitania das Minas ${ }^{20}$.

Nas duas últimas décadas, diversos autores lançaram novas abordagens sobre a cidade colonial brasileira. Beatriz Picollotto Siqueira Bueno e Renata Malcher de Araújo trouxeram importantes contribuições ao estudo da formação e da atuação dos engenheiros militares - protagonistas de intervenções urbanas realizadas principalmente na costa atlântica e nas zonas fronteiriças, como a Amazônia e o Mato Grosso, mas que também tiveram ações pontuais no hinterland da colônia, inclusive em Minas Gerais ${ }^{21}$. Esses trabalhos, assim como nosso estudo sobre a urbanização mineira no século XVIII, também se destacam pelo fato de não se restringirem à morfologia e à estética urbanas, demonstrando que a criação de vilas, de povoações e de fortificações se inseria num processo mais amplo, de apreensão e de construção do território colonial, e de definição das fronteiras internas e externas da América portuguesa ${ }^{22}$. $\bigcirc$ recente trabalho de Maria Fernanda Derntl sobre a capitania de São Paulo seguiu a mesma orientação23. Já Maria Isabel Chrysóstomo tem publicado diversos estudos sobre a rede urbana e a política administrativa no espaço fluminense nos séculos XVIII e XIX24.

Além do "caráter urbano", outra característica do processo de povoamento de Minas Gerais destacada pelos historiadores é a sua "espontaneidade", a ocupação da região tendo ocorrido muito mais como consequência da iniciativa de particulares (aventureiros, bandeirantes, tropeiros e roceiros) do que devido a uma política explícita de colonização e de urbanização conduzida pela metrópole. Contudo, também já foi observado que o Estado não tardou a se impor na região. A permanência e o desenvolvimento posterior dos arraiais mineiros - e sobretudo sua eventual ascenção à categoria de "vila" ou "cidade" - estiveram sempre ligados, de alguma maneira, aos interesses da metrópole ${ }^{25}$. Além disso, os destinos destas povoações coloniais dependeram também da dinâmica dos poderes locais, e da complexa rede de relações que se constituiu pouco a pouco entre os diversos núcleos. Neste sentido, alguns dos estudos mencionados acima também inovaram no que toca à escala da análise: ao invés de abordar o processo "espontâneo" de gênese ou a fundação ex nihilo 
de uma povoação, procurou-se entender o processo de formação e o funcionamento de toda uma rede de cidades, vilas e arraiais - o que, aliás, permite uma melhor compreensão do significado de cada uma dessas criações urbanas, inclusive no que toca aos aspectos morfológicos.

Com efeito, uma das abordagens essenciais para o desenvolvimento da história da cidade colonial consiste em estudar as relações existentes no interior das redes urbanas - e não apenas no nível regional ou mesmo continental, mas também na escala transoceânica do Império português. $\bigcirc$ trabalho de Maria Fernanda Bicalho sobre o Rio de Janeiro é um bom exemplo desta perspectiva: a autora não se contentou em analisar os mecanismos de controle da forma e do uso do espaço urbano, mas interessou-se sobretudo pelas múltiplas relações socioeconômicas, políticas e geopolíticas - que se teceram entre esta cidade e outras partes do mundo português ${ }^{26}$. Não convém, de fato, dissociar história política e história das cidades e do urbanismo: a formação de redes urbanas, a hierarquização das localidades, os projetos e intervenções urbanas em qualquer escala (incluindo a simples abertura de um novo arruamento) eram processos e acontecimentos que podiam mobilizar tanto instâncias do poder local quanto as autoridades metropolitanas.

Contrastando com os vastos sertões que as envolviam, as povoações de Minas Gerais eram vistas como núcleos de civilização: locus de vida social e religiosa, elas constituíam instrumentos para controlar e submeter a população bastante heterogênea que ali se instalou, servindo também de postos avançados para novos desbravamentos e conquistas. A instituição de vilas com vastos termos (territórios municipais) era o meio utilizado pela Coroa para fazer com que o braço da justiça e do fisco chegasse até os arraiais mais longínquos, fundados nos confins das terras conhecidas e colonizadas.

Ao criar-se uma nova municipalidade, a ereção do pelourinho era um dos rituais obrigatórios. Postada geralmente diante da casa de câmara, esta coluna era um dos principais emblemas das vilas: ela materializava a justiça administrada pelos oficiais da municipalidade, e ali eram açoitados os escravos que recebiam tal condenação. Simples pilar de madeira, ou peça esmeradamente esculpida na pedra, o pelourinho era geralmente designado como o centro geométrico do rossio - terreno que a câmara podia dividir em "chãos" para aforar aos moradores -, mas referia-se também a um território bem mais amplo: o termo. De fato, os pelourinhos mais trabalhados eram coroados por uma esfera armilar, geralmente em ferro. Este símbolo do reinado de D. Manuel representava o mundo descoberto e evangelizado pelos portugueses e, segundo Diogo de Vasconcelos, também significava "o recinto de jurisdição, o mundus civitatis". Ao atentar para o sentido desta expressão latina, damos razão ao historiador mineiro: mundus significa o espaço "ordenado", em oposição a um "espaço caótico" lque pode ser associado ao sertão, segundo a visão etnocêntrica dos colonizadores); civitatis designa a cidade, não do ponto de vista da sua materialidade (urbs), mas significando o conjunto dos seus habitantes, regidos por leis e por uma entidade administrativa. 
27. Cf. Laura de Mello e Souza e Maria Fernanda Bicalho (2000, p. 87).

28. Idem, p. 116, n. 108.

29. Ver Cláudia Damasceno Fonseca (2003b).
A concessão do título de vila a um arraial constituía uma questão bastante polêmica, e deixou muitos rastros documentais. Convém lembrar que "os naturais da colônia, fosse individualmente, fosse por intermédio das câmaras de suas vilas e cidades, tinham o privilégio de se corresponder diretamente com o monarca, utilizando-se de um dispositivo próprio da relação entre vassalos e soberanos desde tempos imemoriais: o chamado direito de petição"27. Através de cartas, requerimentos e representações, os colonos da América portuguesa podiam relatar os sucessos alcançados na busca e na exploração das minas de ouro, ou os sacrifícios exigidos na ocupação dos sertões bravios. Pelos mesmos instrumentos, eles pediam recompensas pelos serviços prestados ao rei - concessões de sesmarias, de cargos administrativos e outras "mercês, tífulos e privilégios" - e podiam também queixar-se "dos maus governantes, expondo as violências e vexames sofridos nos longínquos territórios do império" 28.

No Arquivo Histórico Ultramarino de Lisboa e nos arquivos mineiros, encontra-se um grande volume desses documentos, que impressionam pela variedade das questões e das diferentes escalas espaciais abordadas. Ao pedirem o título de vila, os arraiais procuravam justificar a necessidade do mesmo, destacando suas qualidades e relatando seus problemas. A dificuldade de acesso à justiça é uma questão onipresente nesta documentação - sempre associada ao tamanho dos territórios municipais e à centralidade das sedes - mas outros tipos de argumentos eram também mobilizados: a "comodidade" e a salubridade do sítio urbano, a "qualidade" dos seus habitantes, a "nobreza" de seus templos, a necessidade de se realizarem obras públicas (pontes, calçadas, chafarizes). Tais ocasiões constituem, portanto, momentos privilegiados para compreender as "virtudes" e papéis que eram atribuídos às sedes dos concelhos (municípios), e também para identificar as definições coevas do "urbano" e da "cidade" que estão implícitas na hierarquia urbana de Portugal e de seus domínios durante o Antigo Regime.

A correspondência trocada entre a metrópole e a capitania, assim como as cartas que circularam dentro dos limites de Minas entre as câmaras, os ouvidores e os governadores revelam também a complexidade das relações existentes entre as unidades da rede urbana mineira. Essas relações interurbanas caracterizavam-se pela emulação e pelo conflito: na segunda metade do século $X V I I I$, a definição dos limites dos concelhos era uma questão que mobilizava as diferentes câmaras de Minas Gerais. Estas disputavam a posse dos novos arraiais surgidos nos confins imprecisos dos seus termos. Outras disputas nasciam do desejo de emancipação de certos arraiais, que pediam o título de vila e o privilégio de ter uma câmara; também a atribuição do título de cidade foi uma questão que atiçou a rivalidade entre as vilas existentes ${ }^{29}$. 
30. No entanto, destas, somente 54 eram freguesias coladas; ver Cláudia Damasceno Fonseca (2003a, cap.2).

No fim do período colonial, a rede urbana mineira compunha-se de várias centenas de arraiais - dos quais 89 constituíam sedes de freguesias ${ }^{30}$-, de quinze vilas e de uma só cidade: Mariana, a antiga Vila do Carmo, que recebeu o título em 1745, ao se tornar sede episcopal. Ora, este número de sedes de concelho (dezesseis) parece bastante pouco expressivo, tanto em relação ao número de arraiais existentes em Minas - mais de trezentos - quanto ao total de vilas criadas na colônia. Como observou Francisco lglésias, esse número não traduz o quadro real, já que a urbanização em Minas Gerais foi mais efetiva que em outras regiões ${ }^{31}$. Também o número de freguesias mineiras (em 1752 havia cerca de 60) é bastante reduzido em relação à grande extensão territorial da capitania, sobretudo se o comparamos às estatísticas da administração civil e eclesiástica do Reino: em 1745, havia 3987 freguesias e várias centenas de sedes de concelhos (vilas e cidades) no diminuto espaço continental português ${ }^{32}$.

Ao se examinar a cronologia e a distribuição geográfica das vilas mineiras, emergem algumas constatações ${ }^{33}$ e muitas perguntas, que foram o ponto de partida de nossas investigações. As três primeiras municipalidades de Minas surgiram em 171 1: Nossa Senhora do Ribeirão do Carmo (atual Mariana), Vila Rica (Ouro Preto), e Vila Real do Sabará. Em 1713, criou-se a Vila de São João del-Rei e, no ano seguinte, Vila Nova da Rainha e Vila do Príncipe las atuais Caeté e Serro, ambas em 1714). Em 1715, foi a vez da Vila de Piedade do Pitangui e, em 1718, de São José del-Rei (hoje Tiradentes). Depois de mais de uma década sem promoções urbanas, a Vila de Nossa Senhora do Bom Sucesso das Minas Novas do Araçuaí (Minas Novas) foi instalada em 1730. Seguiu-se um intervalo ainda mais longo: somente no final do século é que foram criadas as vilas de São Bento do Tamanduá (atual Itapecerica, 1789), Queluz (atual Conselheiro Lafaiete, 1790), Barbacena (1791), Campanha da Princesa (Campanha, 1798) e Paracatu do Príncipe (Paracatu, 1798). Finalmente, em 1814 , erigiram-se as duas últimas vilas mineiras do período colonial: São Carlos do Jacuí e Santa Maria de Baependi, que retiraram boa parte do imenso território da Vila da Campanha. Note-se ainda que, entre 1711 e 1814, tais instituições ocorrem em dois momentos principais, e em regiões distintas. Mais da metade das vilas surgem no período compreendido entre 1711 e 1730, em importantes núcleos mineradores distribuídos ao longo da Serra do Espinhaço. Por outro lado, no período 1789-1814, a quase totalidade dos arraiais promovidos situa-se na porção sul da capitania, correspondente à Comarca do Rio das Mortes - à exceção de Paracatu, pertencente à Comarca de Rio das Velhas, e situado nos confins ocidentais da capitania. Entre esses "ímpetos fundadores", há várias fases sem nenhuma nova vila, a mais longa tendo durado 59 anos (de 1730 à 1789) (Figura 1).

Para explicar a configuração da hierarquia urbana mineira do final do Setecentos, pareceu-nos essencial levar em conta o que ocorre neste intervalo
31. Ver Francisco Iglésias (1960).

32. Ver Antonio Manuel Hespanha e Ana Cristina Nogueira da Silva (1993); e Cláudia Damasceno Fonseca (2003a).

33. Cf. Caio Boschi (1994b, p. 104). 


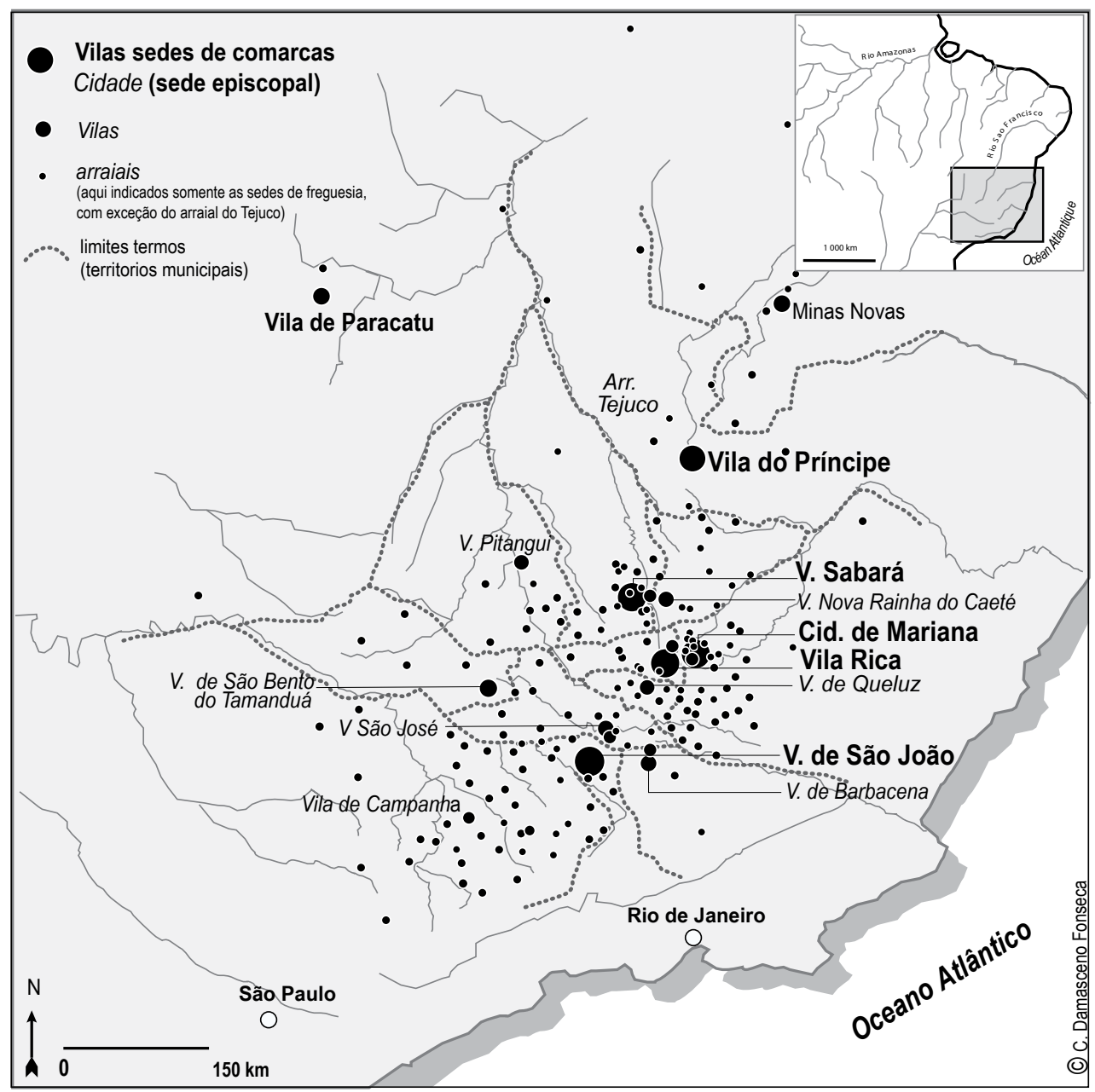

Figura 1 - Hierarquias urbanas em Minas Gerais no final do século XVIII.

Como justificar a ausência de novas vilas durante quase sessenta anos, sendo que se trata de um período de relativa prosperidade? De fato, como é sabido, a historiografia das últimas três décadas demonstrou a impropriedade das antigas teses sobre a "estagnação" da economia mineira a partir de meados do século XVIII, quando declina a produção aurífera. Durante este período, o povoamento dissemina-se pelas regiões periféricas, afastadas dos principais centros de poder, e ele se deve menos à mineração que às atividades agropecuárias e comerciais. Surgem, então, dezenas de novos arraiais, sobretudo na parte sul da capitania. Estes últimos tiveram uma importância primordial na história econômica e territorial não só de Minas, mas de toda a colônia. Na segunda metade do século, a produção e a circulação de mercadorias pela capitania proporcionava rendas vultosas à Coroa, e fazia a fortuna de muitos negociantes. Quando se leva em conta todo o período colonial, percebe-se que a atividade econômica que deu 
origem à maior parte das povoações mineiras não é a mineração, mas a agropecuária (Figura 2).

Nesta segunda fase da história econômica mineira, a gênese e o crescimento das povoações estiveram, mais que nunca, ligados ao comércio. $\mathrm{Na}$ antiga zona mineradora, os arraiais e vilas apresentavam, então, quadros variados de estabilidade, de prosperidade, ou de decadência, dependendo dos trunfos de que dispunham para adaptar-se ao novo contexto. É claro que, em qualquer tempo, a acessibilidade e a situação favorável em relação à rede de caminhos eram qualidades importantes para o desenvolvimento das povoações, mas outros fatores podiam intervir de maneira determinante. Note-se ainda que, embora seu acesso fosse dificultado pelo relevo acidentado, a capital Vila Rica permaneceu, durante todo o Setecentos, e mesmo no século seguinte, como um importante entreposto de mercadorias vindas de diversas zonas mineiras, de outras capitanias ou mesmo da metrópole. Neste caso, a função de capital foi essencial para que a vila se mantivesse como a mais populosa e das mais ricas das Minas. Cabe observar, além disso, que a vocação comercial nem sempre foi decisiva para definir a hierarquia urbana. Se os arraiais de Igreja Nova e Carijós (futuras vilas de Barbacena e Queluz) tinham a vantagem de estar à beira do Caminho Novo,

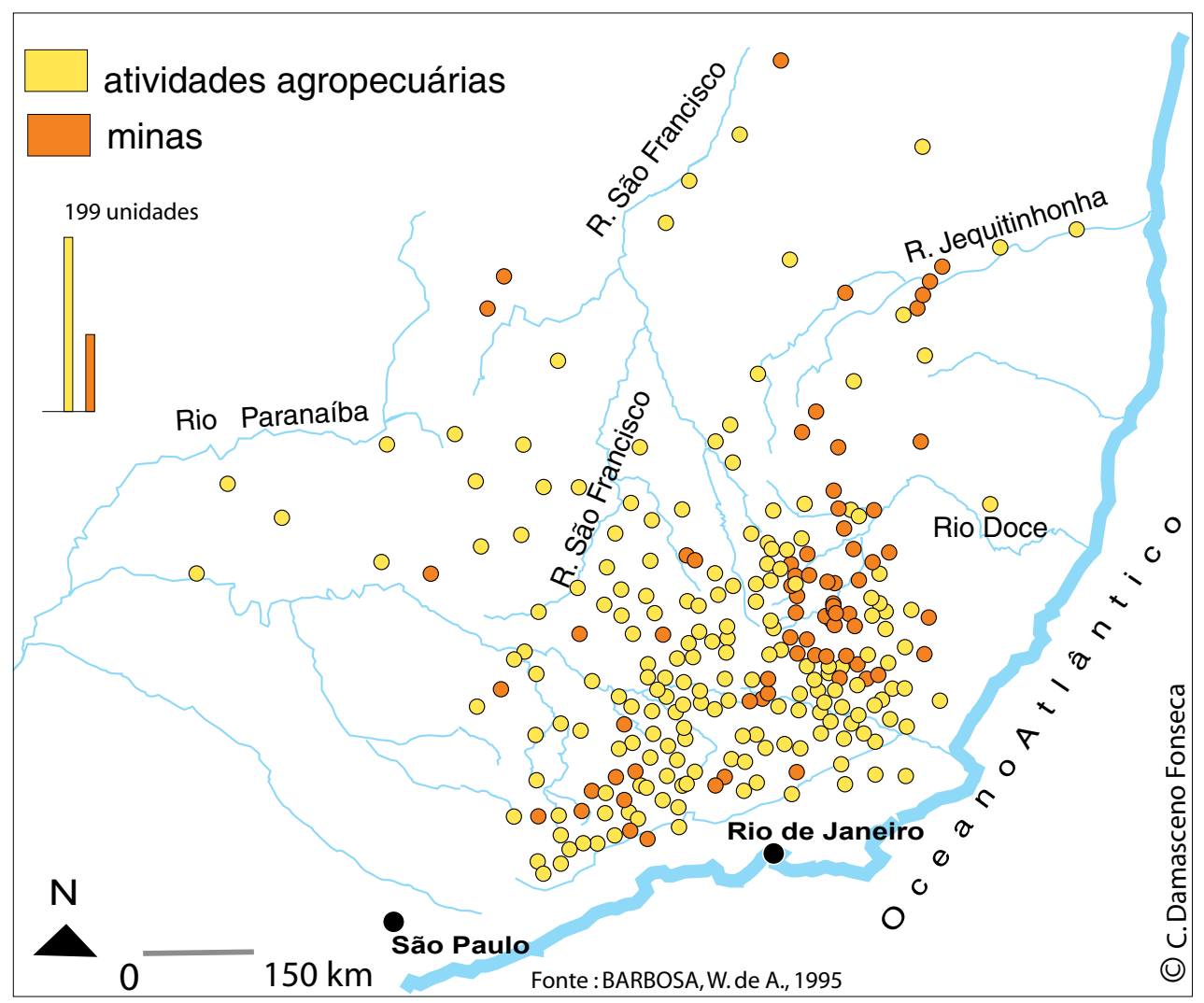

Figura 2 - Origens das povoações mineiras do século XVIII. 
34. Cf. Waldemar de Almeida Barbosa, s. v. SANTA LUZIA (1995).

35. Cf. José Honório Rodrigues (1951, p. 219). que conduzia ao Rio de Janeiro, a situação de Campanha era, por outro lado, desfavorável em relação às estradas principais. Santa Luzia não se tornou vila antes de 1847, apesar de constituir, já em meados do século, um verdadeiro empório: pelo arraial passava "a estrada tão famigerada como geral, de todos os sertões do grande Rio São Francisco, Bahia, Pernambuco e Maranhão" 34 , e também de Goiás. $\bigcirc$ dinamismo comercial e a situação em relação à rede de caminhos não era, portanto, condição necessária nem suficiente para a criação de uma vila.

$\bigcirc$ fato de que diversos arraiais florescentes - como Tejuco, Santa Luzia, Santa Bárbara, entre outros - tenham solicitado, em vão, o título de vila, levou-nos a formular diversas questões. Será que as localidades preteridas não preenchiam as condições exigidas para acederem à promoção urbana? Ou essas recusas decorrem de estratégias da Coroa, ou de disputas políticas locais? Quais foram os fatores que permitiram a alguns arraiais conseguirem o título? Quais eram os critérios adotados para avaliar a "capacidade" dos arraiais para se tornarem sedes de concelhos? De que maneira os contemporâneos hierarquizavam suas povoações? Será que todas as unidades da rede urbana da Minas colonial poderiam ser consideradas como realmente "urbanas", segundo as definições atuais? As petições e requerimentos enviados pelos habitantes lou melhor, pelos "homens principais") dos arraiais, os pareceres das diversas autoridades da capitania (governadores, procuradores da Fazenda Real, ouvidores), as reações das câmaras existentes, bem como as "consultas" do Conselho Ultramarino forneceram diversas pistas para tentar responder a tais questões.

Os primeiros projetos de organização político-territorial da região mineradora datam do início do século XVIII, período da chamada guerra dos emboabas, quando a Coroa percebeu a necessidade de se planejar a instalação do poder (civil e eclesiástico) nos sertões de Minas. Em 17 de julho de 1709, o Conselho Ultramarino reunia-se para discutir questões de suma importância: a arrecadação dos quintos do ouro, a melhoria das defesas da costa do Rio de Janeiro e, acima de tudo, a "administração da justiça e o governo político da gente que assiste e trabalha nas minas do ouro" 35 . A concessão do título de vila a determinados arraiais constituía uma das principais medidas a serem tomadas para acalmar os ânimos da população e para cobrar os impostos devidos ao rei. Com a criação de câmaras nas povoações mais importantes, estas disporiam de juízes para administrar a justiça em primeira instância, e algumas delas poderiam ter ouvidores para as apelações (as vilas sedes de comarca). Por outro lado, a distribuição equitativa dos ofícios judiciários e administrativos entre os poderosos locais poderia contribuir para o fim das disputas entre as diferentes facções de mineiros. Além disso, se situadas estrategicamente, tais vilas poderiam desempenhar outros papéis: centros de coleta do quinto, alfândegas, praças de armas e "presídios" (postos militares avançados). Os dois últimos eram particularmente importantes: na visão dos conselheiros, além dos contrabandistas, os sertões das minas poderiam constituir refúgio para outros inimigos da Coroa: os insurretos e os quilombolas, que, temia-se, poderiam fazer "entre aquelas 
brenhas mais prejudiciais mocambos que os dos Palmares" 36 . Para facilitar e controlar o recebimento dos quintos, também seria desejável que as principais zonas que compunham a região mineradora - Ouro Preto, Rio das Mortes e Rio das Velhas - adquirissem o estatuto de comarcas, cada uma delas tendo uma vila por sede, na qual residiria um ouvidor e corregedor com atribuições judiciárias e fiscais. Estas três vilas deveriam se situar na extremidade dos principais caminhos que ligavam as Minas à Bahia, a São Paulo e ao Rio de Janeiro. Por fim, uma dessas povoações-sede - preferencialmente, a que fosse mais central em relação aos diversos pólos mineradores - deveria ser escolhida para residência do governador, praça de armas e capital da capitania. Segundo alguns conselheiros, ela também poderia receber o título de cidade, que, tanto na metrópole como na colônia, era um privilégio atribuído a povoações com função defensiva, assim como às sedes de bispado.

Mas nem todas as orientações do Conselho Ultramarino quanto à criação das vilas puderam ser aplicadas. Devido a contingências de ordem política, as três primeiras ereções não contemplaram exatamente as mesmas localidades sugeridas pelos conselheiros. Em 171 1, foram criadas, na zona do Ouro Preto, não uma, mas duas vilas: Nossa Senhora do Ribeirão do Carmo e Vila Rica, que disputariam durante vários anos as funções de sede de comarca, de capital da capitania e, mesmo a de cidade episcopal ${ }^{37}$. Na comarca do Rio das Velhas, o governador Antônio de Albuquerque concedeu título de vila le a função de cabeça de comarcal à sede da paróquia de Nossa Senhora da Conceição da Barra de Sabará. Por outro lado, a primeira vila da região do Rio das Mortes surgiu somente dois anos depois, em 1713, no arraial previamente indicado pelos conselheiros, o qual deu origem à Vila São João del-Rei. Para melhorar a administração da justiça e a cobrança dos impostos, outras vilas seriam criadas nos anos seguintes, nas ouvidorias do Rio das Velhas (Caeté em 1714, Pitangui em 1715) e do Rio das Mortes (São José, em 1718), assim como na zona do Serro do Frio (Vila do Príncipe, em 1714), onde surge, em 1720, uma nova comarca $^{38}$.

A partir da década de 1720, após as violentas sedições de Pitangui e de Vila Rica, os governadores de Minas passaram a exprimir uma verdadeira aversão ao poder local, e uma oposição sistemática à criação de novas câmaras. De acordo com D. Lourenço de Almeida, estas últimas constituíam "oficinas de vassalos desobedientes"; numa carta de abril de 1722, o capitão-general chegou a afirmar que "antes se fora possível extinguir muitas das [vilas] que estão criadas, seria Vossa Majestade nessas Minas mais bem servido e mais obedecido" 39 . No entanto, no fim de seu mandato, D. Lourenço foi obrigado a conformar-se com a criação de uma nova câmara. Em outubro de 1730, surgia a Vila de Minas Novas, no vale do Jequitinhonha, onde paulistas haviam descoberto ouro e diamantes. Durante mais de duas décadas, Minas Novas ficou subordinada militarmente à Bahia; somente em 1757, Gomes Freire de Andrada conseguiu convencer o Rei a passá-la para o controle dos governadores e capitães-generais de Minas, argumentando que as autoridades baianas, estabelecidas a uma
36. Idem, p. 240.

37. Ver Cláudia Damasceno Fonseca (2003b).

38. Idem, 2003a.

39. CARTA de Dom Lourenço de Almeida... (1980, p. 113-114). 
40. Ver Cláudia Damasceno Fonseca (2003a, cap. 3 e 4).

41. Ibidem. distância de mais de duzentas léguas, não eram capazes de combater o contrabando de diamantes extraídos da comarca de Serro do Frio.

Como mencionamos, após a criação da Vila de Minas Novas, muitos anos se passaram antes que as autoridades metropolitanas e coloniais decidissem fundar novas vilas na capitania. Por um lado, os problemas que haviam justificado a criação das primeiras câmaras - ou seja, os conflitos entre paulistas e emboabas, e a necessidade organizar a produção aurífera e a arrecadação dos quintos - já estavam, em grande parte, resolvidos. Do ponto de vista dos governadores, nas regiões mais centrais e povoadas da capitania já havia um número suficiente de câmaras. Gomes Freire de Andrada parece ter compartilhado da opinião de D. Lourenço de Almeida: embora vários dos arraiais que solicitaram o título de vila fossem povoações consideráveis em termos demográficos e comerciais, o governador não apoiou nenhuma dessas iniciativas durante os vinte e oito anos de seu mandato (1735-1763) 40 .

Nas petições dos arraiais, para justificar a necessidade da criação de uma vila, encontram-se argumentos variados. O principal deles era a "necessidade de justiças" ressentida pela população dos arraiais. Ou seja, a necessidade de maior proximidade com os juízes e tabeliães, a fim de evitar as longas jornadas até as vilas, que encareciam os processos e os atos notariais. Esse argumento reflete o pensamento político dominante da época, que considera "a boa administração da justiça" - no sentido da proximidade e da qualidade dos juízes - como uma das condições essenciais à "felicidade" e ao "bem comum dos povos". Mas a maior parte desses pedidos foi recusada, por uma ou várias razões. Em alguns casos, os governadores julgaram falaciosas as justificativas dos habitantes a respeito da falta de juízes e tabeliães; em outros, o requerimento provocou reações de oposição das autoridades locais (ouvidores, câmaras), que tinham de ser ouvidas em tais circunstâncias. Enfim, em certas regiões da capitania e em contextos específicos, a criação de um novo centro de poder local foi descartada por parecer prejudicial aos interesses régios.

No entanto, entre 1730 e o final da década de 1780, houve momentos em que os sucessivos governadores julgaram conveniente atender às demandas dos moradores das Minas. Isto não foi feito através da criação de novas vilas (ou seja, de novos concelhos, com as respectivas câmaras), mas por meio de medidas que paliavam a "falta de justiças" da qual se queixavam os peticionários. Em alguns casos, eles nomearam oficiais judiciários suplementares - tabeliães, juízes de vintena - para cuidar destas populações; em outros casos, criaram uma nova circunscrição judiciária - o julgado -, cuja sede se situava no arraial solicitante. Resolver os problemas individuais dos moradores das Minas não era, porém, o único objetivo da criação de um julgado. Muitas vezes, a instituição dessas circunscrições participava de uma estratégia dos governadores, que procuravam estender e consolidar seus territórios de jurisdição - ou seja, a própria capitania. Também a criação de freguesias nos confins das Minas incluíase nesta visão geopolítica ${ }^{41}$. 
Da mesma forma, a fundação de novas vilas no fim do período colonial também deve ser relacionada à política de expansão dos limites de Minas Gerais - lembre-se de que a parte meridional da capitania londe foi instituída a poderosa vila da Campanha, em 1798) era disputada por São Paulo, enquanto os confins ocidentais (em torno da Vila de Paracatu, fundada em 1798) eram cobiçados pelas autoridades de Goiás. Por fim, a correspondência oficial, bem como diversos estudos históricos sobre o período demonstram que a criação das vilas de São Bento do Tamanduá, Queluz e Barbacena, entre 1789 e 1791 , também esteve intimamente relacionada ao contexto político instável da capitania, que se fez sentir de maneira violenta por ocasião das devassas da inconfidência mineira: de fato, nestas três freguesias (Tamanduá, Carijós, Igreja Nova) viviam pessoas importantes que estiveram implicadas no movimento, e cujo apoio era fundamental para o governador visconde de Barbacena ${ }^{42}$. Note-se, aliás, que o visconde erigiu essas três vilas sem a necessária autorização de Lisboa le foi repreendido por issol, ao mesmo tempo em que preteriu a criação das vilas de Campanha e de Paracatu, que havia sido preconizada pelo Conselho Ultramarino. Tal escolha se explica certamente pelo fato de que, no âmbito dos projetos iluministas de reforma da organização judiciária, a Coroa decidira atribuir juízes de fora às duas vilas desde o momento de sua fundação, e a presença de tais magistrados certamente poderia ter prejudicado os arranjos políticos do visconde ${ }^{43}$. Portanto, é necessário levar em conta diferentes elementos para que se possa compreender a evolução da malha territorial e da hierarquia urbana mineira: a situação geográfica dos arraiais e vilas existentes, sua posição em relação à rede de caminhos e às fronteiras da capitania, as relações entre os governadores e as elites locais, bem como entre os magistrados e oficiais judiciários. Também é importante que se examinem as relações entre as vilas, bem como as ligações existentes entre cada sede municipal e os arraiais dela dependentes, pois foram determinantes para a formação dos limites internos da capitania - tanto os dos concelhos quanto os das comarcas. Focalizar conflitos territoriais entre as unidades da rede urbana mineira fornece outras chaves para explicar as concessões dos títulos de vila na segunda metade do século, assim como para compreender o fracasso das tentativas de emancipação de certos arraiais. Note-se, a propósito, que alguns dos arraiais promovidos a vilas entre 1789 e 1791 situavam-se em zonas que eram objeto de disputas territoriais entre duas ou mais câmaras: tal foi o caso nomeadamente de Tamanduá e Carijós ${ }^{44}$. De fato, esses centros do poder civil e religioso não eram núcleos inertes, ou entidades passivas. As "cabeças" das circunscrições (comarcas, concelhos, freguesias) mantinham entre si vários tipos de relações, e cada uma delas também interagia com os arraiais e com as zonas rurais circunvizinhas, que thes estavam subordinadas. Essas relações, muitas vezes conflituosas, condicionavam a criação de novas freguesias e concelhos, e também podiam influir na gestão dos espaços urbanos ${ }^{45}$.
42. Ver Cláudia Damasceno Fonseca (2003a, cap. 4). Este aspecto já havia sido abordado, de maneira superficial, tanto nos estudos de eruditos locais, como Nestor Massena (1985), quanto em análises mais recentes sobre a Inconfidência Mineira que, embora interessadas por outras questões, dedicaram alguma atenção à criação das vilas de Barbacena e Campanha (Furtado 2002, p. 159-160).

43. Idem, cap. 4.

44. Idem, cap. 5.

45. Idem, cap. 5-7. 
46. Cf. Bernard Lepetit (1981, p. 35).

47. Ver Cláudia Damasceno Fonseca (2000).
A morfologia das vilas e dos arraiais: representações e interpretações

Além dos conflitos territoriais, a correspondência oficial da capitania trata de aspectos que pertencem a uma outra escala do fenômeno urbano: a estrutura fundiária das povoações, a construção e o controle dos espaços e equipamentos públicos, ou seja, todo um conjunto de questões ligadas ao "urbanismo". Como observou Bernard Lepetit, se esta palavra é relativamente recente - suas primeiras ocorrências em línguas latinas datam de meados do século XIX -, "a prática é antiga". Para identificá-la durante o século XVIII, basta que se defina o urbanismo como um "conjunto de medidas técnicas, jurídicas e econômicas que permitem uma intervenção ou um desenvolvimento autônomo das cidades"46. Desta forma, podemos considerar como "urbanísticos" diversos aspectos relacionados à materialidade das povoações mineiras: a delimitação e a gestão dos rossios e dos chãos foreiros, o direito de utilização das nascentes, o sistema de adução d'água, a abertura, a regularização, a pavimentação e a conservação das ruas e praças, o financiamento e a construção de pontes e chafarizes. Várias dessas questões suscitaram querelas entre as câmaras e os moradores. Algumas foram resolvidas localmente, e podem ser estudadas pela documentação dos arquivos mineiros. Outros casos tiveram de ser arbitrados pelo rei e pelo seu Conselho Ultramarino, pois os interesses em jogo extrapolavam a esfera municipal. Além da correspondência oficial, que faz menção a tais situções conflituosas, o tema da gestão do espaço urbano também aparece em outros tipos de fontes conservadas nos arquivos municipais: registros de bandos e editais, livros de aforamentos e de tombo de propriedades foreiras, entre outros.

Nas Minas Gerais, as intervenções da Coroa na fundação e no desenvolvimento físico das povoações foram menos sistemáticas e explícitas do que em outras regiões da América portuguesa - e, consequentemente, são menos facilmente identificáveis pelo historiador. $\bigcirc$ contexto particular da capitania fez com que a metrópole se preocupasse mais com questões fiscais e com o controle social do que com problemas de urbanismo. Raros foram os engenheiros enviados à região, e esses raramente intervieram em questões urbanísticas ${ }^{47}$. Assim sendo, os primeiros pesquisadores que se interessaram pela urbanização mineira seguiram, naturalmente, uma orientação distinta da que identificamos em outros estudos publicados entre as décadas de 1950 e 1970: como foi mencionado, em vez de investigar a existência de traçados geométricos e de medidas regularizadoras nas povoações mineiras, Paulo Santos e Sylvio de Vasconcellos preferiram destacar as qualidades estéticas nos traçados urbanos "informais", "irregulares" ou "orgânicos".

Num texto de 1959, Sylvio de Vasconcellos apresentava os exemplos da cidade de Mariana e do arraial do Tejuco (atual Diamantina) como casos excepcionais, que fugiam à regra geral da "linearidade", da "espontaneidade" e da "irregularidade" que caracterizavam as aglomerações mineradoras - sendo estas geralmente constituídas pela justaposição de pequenos acampamentos nas 
encostas e às margens dos ribeiros auríferos. Segundo ele, os traçados "compactos" e "reticulares" das duas localidades eram semelhantes aos adotados em certas cidades litorâneas (Rio de Janeiro, Salvador, Belém), e estariam "mais de acordo com os princípios urbanísticos recomendados pela administração portuguesa" ${ }^{\prime 4}$. Na tentativa de explicar essas conformações particulares, o autor relembrou, com propriedade, os contextos politico-econômicos singulares nos quais se inseriam ambas as povoações no período colonial. $\bigcirc$ Tejuco era sede da Demarcação Diamantina e local de residência dos poderosos intendentes; poder-se-ia supor que estes tivessem tomado iniciativas tendentes à regularização do tecido urbano (hipótese dificilmente verificável, devido à falta de documentação), já que a vila do Tejuco (e sua primeira câmara) só foi criada em 1831 . Quanto a Mariana, o autor reproduziu a explicação dada pelos historiadores mineiros que o precederam: de que o traçado da cidade teria sido objeto de um "plano" executado em meados do século XVIII, quando da promoção da Vila do Carmo à condição de cidade episcopal - plano este que teria sido encomendado por D. João $V$ ao engenheiro militar José Fernandes Pinto Alpoim, que se encontrava em Minas naquele período. Porém, Sylvio de Vasconcelos não levou adiante a análise de tais exemplos "excepcionais": se o arraial do Tejuco foi tema de um interessante artigo ${ }^{49}$, Mariana não mereceu mais do que referências rápidas em seus estudos sobre a formação das povoações mineiras ou, ainda, na obra que dedicou à Vila Rica ${ }^{50}$. Isso talvez se explique por um desejo de desviar-se um pouco das pegadas do pai, Salomão de Vasconcellos: como é sabido, este grande conhecedor dos arquivos marianenses publicou diversos livros sobre a cidade a partir da década de 1930 e precedeu Sylvio enquanto colaborador do Instituto do Patrimônio Histórico e Artístico Nacional ${ }^{51}$.

Em obras posteriores, Mariana aparece novamente como um exemplo excepcional de traçado regular em Minas, mas seu estudo não foi aprofundado: Roberta Marx Delson consultou fontes primárias importantes (algumas delas já presentes nos trabalhos de Sylvio de Vasconcellos, que não foi todavia citado), mas a análise do processo de constituição do novo traçado da cidade ocupa apenas quatro parágrafos de seu livro, e suas conclusões foram, em alguns casos, um pouco apressadas ${ }^{52}$. Em 1993, ao constatar essas lacunas, decidimos escolher Mariana como tema de nossa dissertação de mestrado. Esta consistiu em um estudo sobre a gênese e a evolução urbana (do século XVIII ao século XX), realizado no âmbito da geografia cultural (com ênfase na questão da preservação patrimonial), e apoiado na cartografia histórica de Minas Gerais (então pouco conhecida e explorada pelos historiadores) $)^{53}$. Os estudos pioneiros de Salomão de Vasconcellos, bem como os trabalhos efetuados pelo cônego Raimundo Trindade ${ }^{54}$ constituíram ponto de partida e referências essenciais para a pesquisa, que contemplou apenas uma pequena parte das fontes primárias existentes. Entre 1996 e 1998, partes dessa dissertação foram publicadas em diversos artigos, e, paralelamente, o trabalho sobre os arquivos portugueses e brasileiros pôde ser aprofundado 55 . Não cabe aqui resumir tais estudos, mas tão somente enfatizar algumas questões importantes ali tratadas e sinalizar as possibilidades que se
48. Cf. Sylvio de Vasconcellos (1959b, p. 121).

49. Idem, $1959 \mathrm{~b}$

50. Idem, 1956.

51.Ver, entre outros, Salomão de Vasconcelos (1947).

52. Cf. Roberta Marx Delson (1979, p. 66-67).

53. Ver Cláudia Damasceno Fonseca (1995).

54.Ver Raymundo Octavio da Trindade (1945).

55. Ver, especialmente Cláudia Damasceno Fonseca (1998a, 1998b). 
56. Este Mapa, atribuído a Alpoim, está em Nestor Goulart Reis Filho (2000), e também em Cláudia Damasceno Fonseca (2003); e Antônio Gilberto Costa (2004).

57. Ver Cláudia Damasceno Fonseca (2000). abrem a partir de uma exploração mais sistemática, informatizada e "espacializada" das fontes primárias concernentes às vilas e arraiais mineiros.

Como foi referido, a historiografia veiculou a ideia de que Mariana seria o único núcleo setecentista de Minas Gerais a apresentar um traçado regular, atribuído a Alpoim. A existência de uma planta que, embora contendo várias imprecisões, segue as convenções da cartografia militar, reforçou a ideia de uma intervenção urbana totalmente calcada no projeto do engenheiro ${ }^{50}$ (Figura 3). A realidade é, no entanto, bem mais complexa. Se, por um lado, é certo que a sede do bispado mineiro constitui o exemplo mais evidente e documentado que se conhece de intervenções regularizadoras em Minas, por outro pudemos comprovar que não se trata de um caso isolado 57 , e que o traçado do chamado "centro histórico" não deve ser associado exclusivamente ao "plano Alpoim" - sobre o qual, aliás, pairam várias dúvidas, já que a correspondência oficial demonstra que ele não participou de decisões essenciais, como a localização da "nova praça" da cidade la atual praça que reúne a Casa de Câmara e as igrejas de

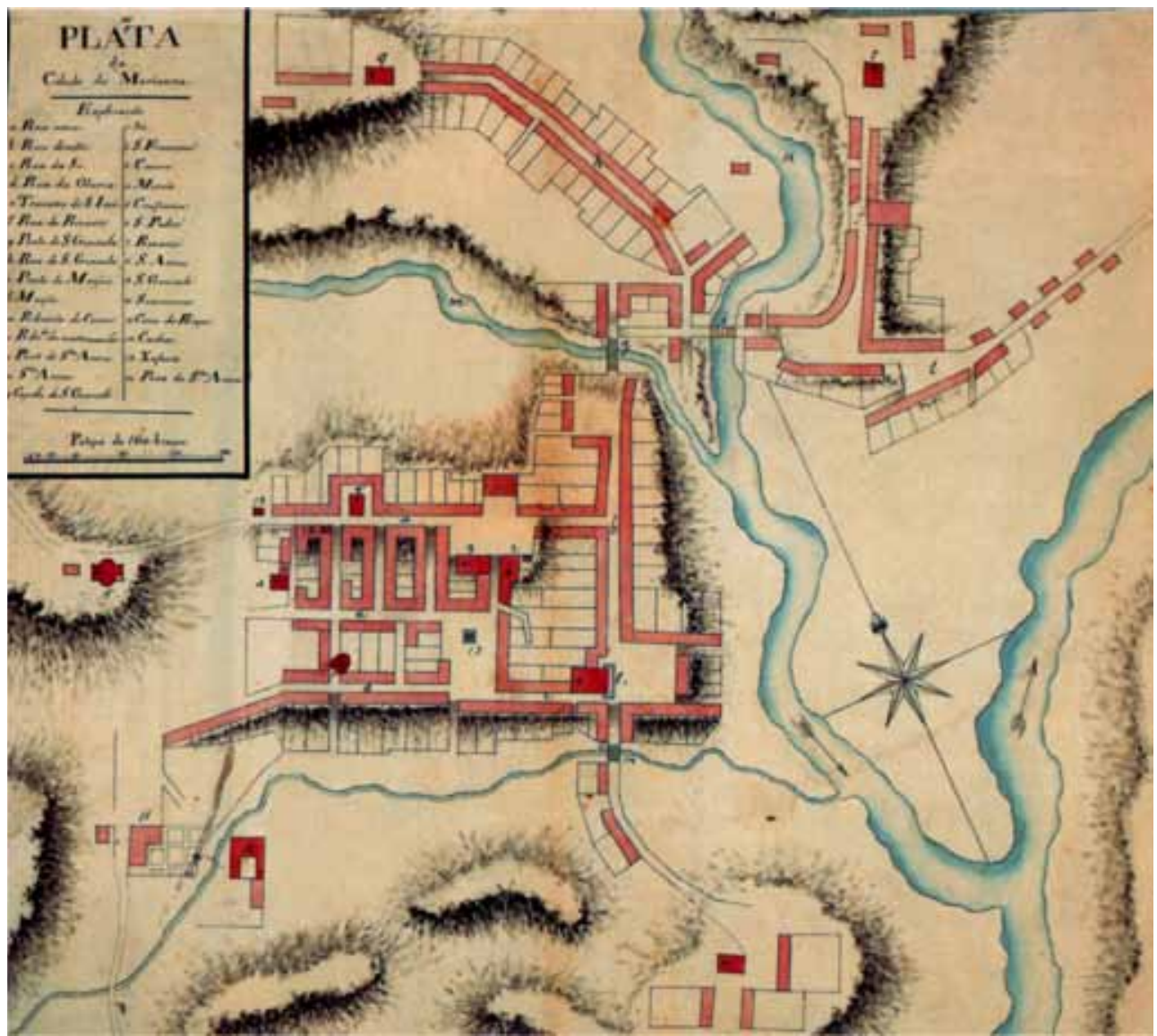

Figura 3 - José F. Pinto Alpoim (atribuído). Plãta da Cidade de Mariana. Arquivo Histórico do Exército, Rio de Janeiro. O traçado indicado na planta não corresponde ao que foi executado. Algumas travessas só foram abertas (e os terrenos aforados) após 1752. 
São Francisco e Nossa Senhora do Carmol. Outros indivíduos, e diferentes instâncias do poder civil e religioso, participaram de maneira significativa na construção desse espaço urbano, além da própria população, que também interferiu no processo, ora se submetendo, ora reagindo às decisões das diversas autoridades.

Na verdade, o caráter "excepcional" da trajetória de Mariana no contexto mineiro deve-se bem menos à alegada e possível contribuição do engenheiro Alpoim do que aos problemas ambientais decorrentes da mineração, que exigiram a intensificação do controle municipal (e metropolitano) sobre o uso e a ocupação dos terrenos urbanos. De fato, se Mariana não tivesse sido vítima das recorrentes inundações do Ribeirão do Carmo, a história "urbanística" da cidade teria sido bem diferente. Tais problemas ocorreram justamente no momento em que a localidade era promovida à condição de sede episcopal, e tal decisão a tornou alvo de uma atenção especial da Coroa. Procurando fornecer orientações precisas sobre a forma que as novas ruas e moradias deveriam ter, D. João $V$ se dirigia ao governador Gomes Freire, em setembro de 1745, encarregando-o de "fazer planta e arruamentos das ruas que de novo se devem fazer em sítio livre das inundações do rio" 58 . Suas ordens teriam de ser executadas sem demora, pois a cerimônia de posse do primeiro bispo não poderia ocorrer num cenário de ruínas. $\bigcirc$ processo foi, porém, bastante lento, em parte devido à oposição de diversas autoridades - entre elas o governador Gomes Freire e a Câmara de Vila Rica, pois esta também havia cobiçado o título de cidade e a função de sede episcopal.

Em seguida, pela Ordem Régia de 2 de maio de 1746, D. João V mais uma vez ordenava a feitura de "planta e arruamentos das ruas que de novo se devem fazer em sítio livre das inundações do rio" 59 . Mandara também que se efetuasse a demarcação de uma "praça espaçosa", de ruas "direitas e com bastante largura" e de sítios para os "edifícios públicos" - uma atenção especial sendo dada à escolha do terreno das "casas" que abrigariam as "audiências da câmara" e a cadeia. Os oficiais deveriam em seguida aforar as "braças de terra" que os moradores pedissem para suas casas, as quais haveriam de "fazer face das ruas, cordeadas as paredes em linhas retas, e havendo comodidade para quintais das casas, devem estes ficar pela parte detrás delas, e não pela parte das ruas em que as casas tiverem suas entradas"60. Era o início de uma longa correspondência trocada entre Lisboa, o governador e a câmara de Mariana, em que são frequentes as palavras "aformosear", "aumentar", "preencher" e "dilatar", demonstrando a determinação da Coroa em obter um cenário condizente com a habitual pompa que revestia as cerimônias de posse dos bispos ${ }^{61}$.

No entanto, não se deve esquecer que o traçado reticular implantado a partir de meados do século XVIII (sobre terrenos mais elevados, situados nos "pastos" atrás da matriz-Sé), veio se conectar a uma estrutura urbana preexistente, que constituiu um elemento condicionante para o suposto "projeto" da parte nova da cidade. De fato, a gênese do primitivo arraial de Nossa Senhora do Carmo foi semelhante à de outros núcleos mineradores, apresentando as características
58. Ordem régia de 2 de maio de 1746,Arquivo Público Mineiro, SC. 45, fl. $27 \mathrm{v}$.

59. Arquivo Público Mineiro, SC. 45, f. $27 \mathrm{v}$.

60. Ibidem.

61. Ver Cláudia Damasceno Fonseca (1998b). 
62. Ver Walter Rossa (1998).

63. DIÁRIO da jornada... (1939, p. 313).

64. Não se trata, pois, do bairro onde se encontra a capela de Santana, na parte leste da cidade, mas de um morro situado $3 \mathrm{~km}$ ao norte do centro.

65. Além da questão dos patrimônios religiosos, para a qual chama a atenção Murillo Marx (1991, 1992), deve-se salientar que, antes da criação da vila de Nossa Senhora do Carmo, foi decisiva para o desenvolvimento posterior da povoação uma decisão tomada pelo vigário da freguesia: a transferência dos "foros de matriz" da capela de Nossa Senhora do Carmo ("arraial de cima") para a capela de Nossa Senhora da Conceição (atual Sé); ver Cláudia Damasceno Fonseca (1995, 1998b). que foram evidenciadas nos trabalhos de Sylvio de Vasconcellos. $\bigcirc$ povoado nasceu da justaposição de pequenos acampamentos situados próximo ao ribeirão e sobre os morros auríferos; e, por entre os "ranchos" de garimpeiros, destacavamse os edifícios religiosos (capelas de Nossa Senhora do Carmo, de São Gonçalo, de Santana, e matriz de Nossa Senhora da Conceição), que polarizavam a vida social do arraial. As vias principais prolongavam-se em caminhos que, tomando várias direções, conduziam a outros arraiais mineradores e às zonas rurais (São Sebastião, Taquaral, Antônio Pereira, Itacolomi, Bucão etc.); essas vias conformavam um traçado longilíneo, com ruas seguindo as curvas de nível ou vencendo encostas íngremes.

Tais estruturas viárias primevas estão longe de apresentar a regularidade dos arruamentos construídos na "parte nova" da cidade, mas podem ser consideradas como relativamente "reguladas" - segundo a expressão utilizada por Walter Rossa ${ }^{62}$ - comparativamente a outros assentamentos, na medida em que as casas são, pelo menos, alinhadas e construídas "à face das ruas", mesmo se estas últimas não são retilíneas e não se organizam em forma reticular. De fato, é importante notar que não era em todos os arraiais mineradores que existiam configurações mais ou menos "reguladas" como essas. É o que se percebe na descrição da primitiva São João del-Rei, quando da chegada do governador D. Pedro de Almeida (o conde d'Assumar) às Minas (1717):

Saiu Sua Excelência a ver a vila, que podendo ser a mais bem tratada, digo, plantada das Minas, é das piores, por ter quase todas as casas de palha, e umas muito separadas das outras, e juntamente pelas lavras de ouro, que ficam tão perto delas, que hoje se fazem, amanhã se botam em terra para trabalhar, o que causa toda a irregularidade, e não sucederia isto se aqueles moradores as fabricassem em um plano, onde está situada a lgreja, adonde não há ouro ${ }^{63}$.

Na segunda metade do século XVIII, tal fato se verificava também nos arredores de Mariana (nomeadamente no morro de Santana - um dos arrabaldes situados ao norte ${ }^{64}$ - e no morro de Santo Antônio, em Passagem), bem como em partes do morro do "Ouro Podre" de Vila Rica (Figuras 4 e 5) e no arraial do Tejuco. Documentos textuais e cartográficos indicam, com efeito, que os "ranchos" e casas encontravam-se espalhados pelas encostas, sem seguir um arruamento. Esta parece ter sido uma constante nas áreas em que os serviços de extração aurifera foram mais duradouros.

Que fatores poderiam, então, explicar o surgimento de linhas contínuas de edificações - mesmo que em ruas sinuosas - nos "subúrbios" (palavra empregada na documentação coeval das vilas e em arraiais dos seus termos? Note-se que essa relativa regularidade nem sempre pode ser atribuída à ação das câmaras, que em geral se preocupavam somente com a organização física das sedes dos concelhos - este, aliás, era um motivo de queixa das povoações que pediam o título de vila. É sempre plausível a hipótese da intervenção do poder eclesiástico - que, em alguns casos, está, aliás, comprovada ${ }^{65}$. $\bigcirc$ papel dos 


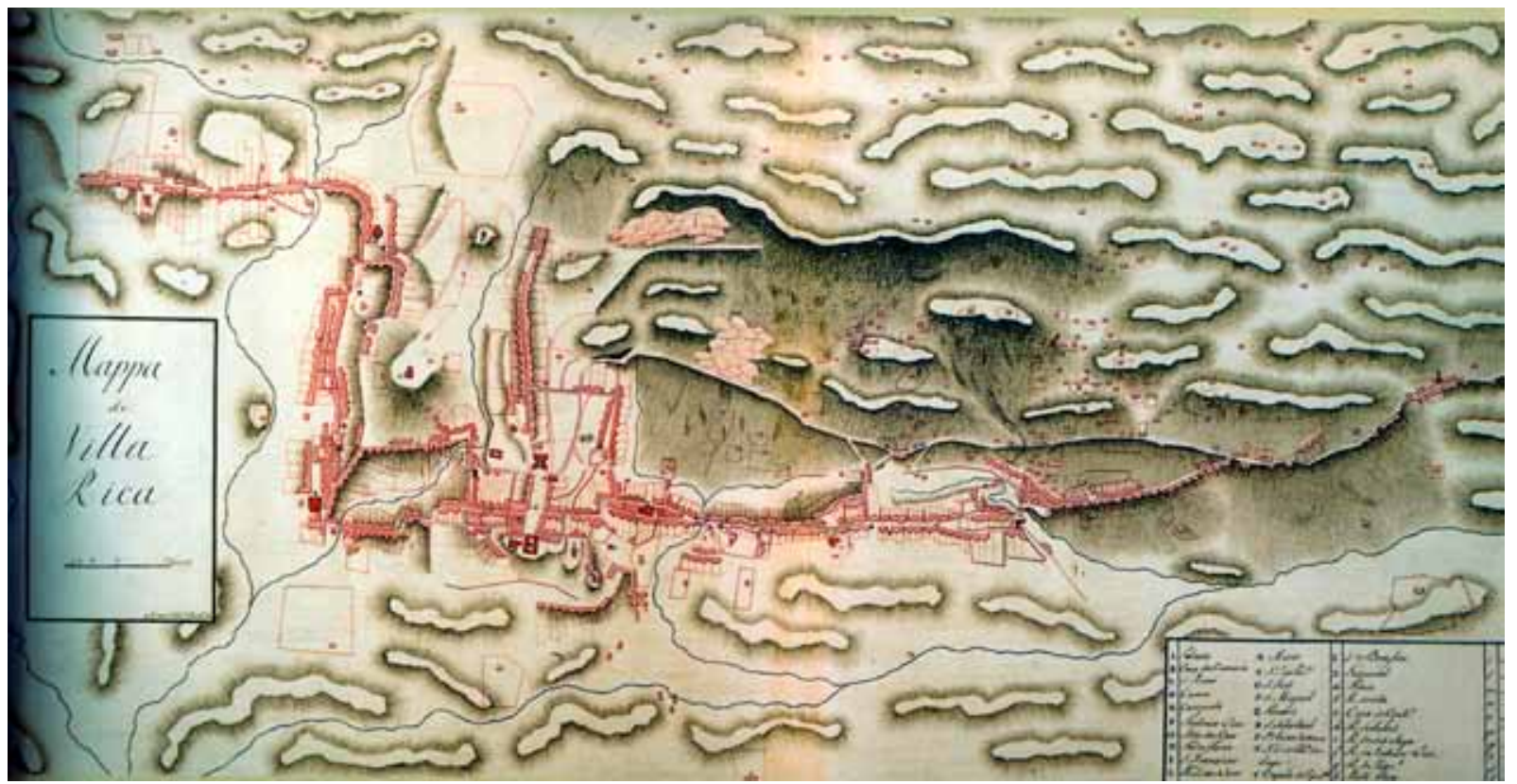

Figuar 4 - Manoel Ribeiro Guimarães. Mappa de Vila Rica. Arquivo Histórico do Exército, Rio de Janeiro. A representação deve ser posterior a 1797, ano em que, segundo Diogo P.R. de Vasconcellos, foi "acabada" a praça principal da vila, com a demolição de algumas casas "que assombravam a nova Casa da câmara" (atual Museu da Inconfidência).

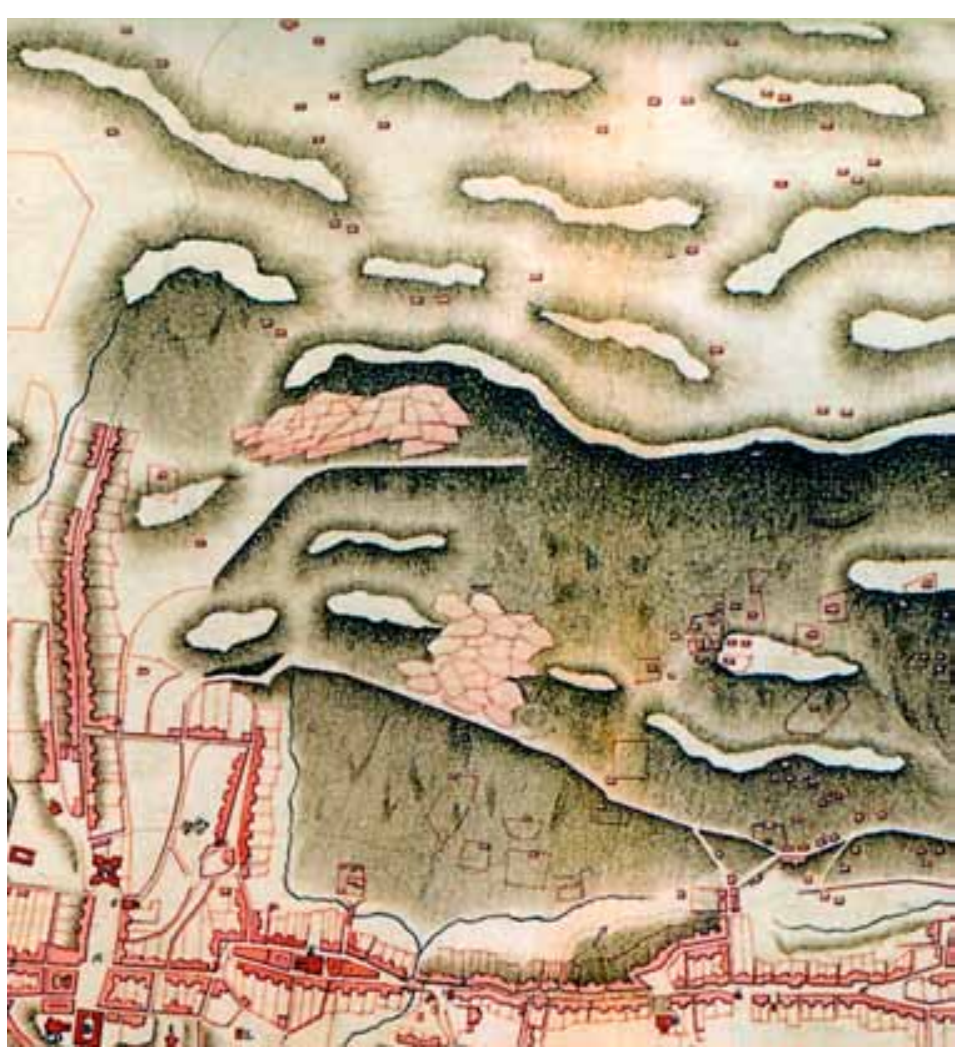

Figura 5 - Detalhe do Mappa de Vila Rica. Nos morros situados na porção norte dos núcleos urbanos de Vila Rica (Morro da Queimada, do Ouro Podre) e de Mariana (Morro de Santana) não havia ruas propriamente ditas, apenas trilhas unindo as moradias, capelas e serviços minerais.

Annals of Museu Paulista. v. 20. n.1. Jan.-Jun. 2012. 
66. Ver Cláudia Damasceno Fonseca (2000).

67. Lembre-se, a propósito, que Rafael Pires Pardinho é referido na correspondência entre Gomes Freire e Alexandre de Gusmão concernente à escolha de Mariana (Vila de Nossa Senhora do Carmo) como sede episcopal, e à organização da "parte nova" da cidade; ver Cláudia Damasceno Fonseca (1998b).

68. Em seu estudo sobre Vila Rica e Mariana, Rodrigo Almeida Bastos (2003) associou tais "condicionamentos" à noção de decoro.

69. Cf. Nestor Goulart Reis Filho (1968, p. 16).

70. Cf.José Joaquim da Rocha (1995, p. 121).

71. Ver José João Teixeira Coelho (1994).

72. Entre os portugueses, observadores e autores, somente Diogo de Vasconcellos emitiu julgamentos positivos sobre Vila Rica. Mais tarde, Saint-Hilaire também considerou "pitorescas" algumas povoações mineiras; ver Cláudia Damasceno Fonseca (1998c, 2008). ouvidores na regularização dos espaços urbanos coloniais também já foi identificado: em 1737 o ouvidor do Rio das Mortes Cipirano da Rocha "deu forma" ao arraial da Campanha ordenando que os "ranchos" dos mineiros fossem construídos "com ordem de ruas, praça e igreja para que não sucedesse a irregularidade que se acha nas Vilas dessas Minas" 60 . As pesquisas recentes le inéditas) de Renata Malcher de Araújo sobre a atuação de Rafael Pires Pardinho na elaboração de "modelos" de cartas de fundação de diversas vilas na colônia (as célebres "cartas régias") também levantam a hipótese de que a maior "regularidade" do Tejuco - identificada por Sylvio de Vasconcellos nos anos 1950 - seja fruto de medidas tomadas pelo bacharel no período em que este exerceu o cargo de Intendente dos Diamantes ${ }^{67}$.

Todavia, não se deve descartar a possibilidade de que a existência de arruamentos "regulados" em certos povoados resulte de iniciativas dos próprios proprietários das casas e chãos. Segundo Nestor Goulart, "a regularidade com que certos elementos se repetem nas implantações coloniais brasileiras" exige que se abandone "a ideia de um fenômeno aleatório" e admita-se a existência de "algumas formas de condicionamento" 68 que estariam "presentes ou não na consciência de todos os indivíduos" 69 . $\bigcirc$ alinhamento das casas junto à testada dos lotes parece constituir uma dessas tradições seculares que podia manifestar-se quando os acampamentos de mineradores se tornavam arraiais estáveis e os ranchos eram substituídos por construções menos precárias. Posteriormente, com a eventual criação do poder civil local, a câmara assumia os papéis que the cabiam, legislando sobre os espaços públicos e procurando aplicar os regulamentos existentes, a fim de alargar e endireitar ruas e praças, demolir edifícios mal implantados e determinar os alinhamentos das novas construções. Foi o que aconteceu, por exemplo, em São João del-Rei: apesar da resistência dos moradores, após o esgotamento dos filões auríferos das encostas, a vila acabou se desenvolvendo num terreno "plano e agradável"70; segundo uma descrição do final do século XVIII, suas ruas eram "vistosas", seus templos e edifícios tinham "alguma nobreza"71.

A propósito, é interessante notar que, na visão dos contemporâneos, os esforços das autoridades municipais nem sempre foram suficientes para dar uma aparência "regular" aos núcleos urbanos. A câmara de Vila Rica foi pródiga nesse tipo de iniciativa e, no entanto, diversos observadores do final do período colonial - magistrados, funcionários régios, viajantes estrangeiros - queixaram-se da "irregularidade" das ruas e da falta de harmonia das fachadas desta e de outras vilas mineiras, embora reconhecessem, por vezes, que seus sítios acidentados podiam proporcionar " 'perspectivas' agradáveis"72. De fato, nas descrições de vilas e arraiais presentes em relatos de funcionários régios - como o intendente Teixeira Coelho, o cartógrafo José Joaquim da Rocha e o bacharel Diogo Pereira Ribeiro de Vasconcellos - podemos identificar diversos pontos em comum. $\bigcirc$ três autores sempre incluem algumas informações geográficas: a posição, em latitudes e longitudes, seguida de uma apreciação do sítio onde a povoação foi implantada, de seu clima, de suas condições de salubridade, e de 
uma enumeração das produções agropecuárias, gêneros comercializados, e recursos naturais mais importantes do seu território ${ }^{73}$. As considerações sobre a forma urbana aparecem sempre relacionadas com os caracteres topográficos: de modo geral, a povoação recebe uma apreciação positiva quando seus terrenos não são demasiadamente acidentados de maneira a permitir a realização de arrumentos "cômodos" e com fachadas num mesmo plano, assim como o "aumento" futuro da urbe. Um exemplo é a descrição de Vila Rica feita por Rocha: "A situaçao desta terra é bastante desagradável, não só pela arquitetura das casas, mas ainda pelo elevado de suas ruas, que fatigam a todos aqueles que as passeiam; porém, é abundante dos víveres necessarios para passar a vida"74.

$\bigcirc$ julgamento arquitetônico e urbanístico de José João Teixeira Coelho não contempla muitas localidades, mas é bastante objetivo em suas observações sobre a forma das vilas, adotando para elas uma fórmula quase padrão; assim, em Sabará, "as ruas são irregulares, os templos e as casas de madeira, e sem nobreza". Da mesma forma, em Vila Nova da Rainha do Caeté as ruas são "irregulares e edifícios pequenos, à exceção da matriz, que é um templo nobre"75. Vila Rica, situada em sítio montanhoso, possui também "ruas irregulares", e seus edifícios são igualmente desprovidos de "nobreza", com exceção dos templos das duas matrizes - do Pilar e Antônio Dias - e das Ordens Terceiras do Carmo e de São Francisco, que são "majestosos e ricos". Os maiores elogios foram para São João del Rei e Mariana: na primeira, "as ruas são vistosas, os templos e mais edifícios têm alguma nobreza"76. Sobre a cidade episcopal, o intendente de Vila Rica escreveu: "O sitio em que está fundada é quase plano e dos mais agradáveis que há nos matos; os ares são puros, e as águas, excelentes. Os edifícios são baixos e de madeira, o arruamento é regular e os templos são decentes"77.

São João del Rei, elogiada por José Joaquim da Rocha, também estava nas graças do doutor Diogo Pereira de Vasconcellos, que a descreveu duas décadas mais tarde (1806): "Muito bem lançada nas margens meridionais do rio das Mortes; um córrego que passa em meio dela a divide em duas partes, que comunicam duas pontes [... A A igreja paroquial de Nossa Senhora do Pilar, vários templos e bons edifícios armam a vila, que é sem dúvida a mais bela da Capitania"78.

De fato, no início do século XIX, o "belo" continuava a ser associado às imagens contidas nas cartas régias setecentistas, remetendo a uma concepção clássica de beleza e de cidade ideal, fundada nos princípios de conveniência, proporção, utilidade. A contiguidade e o alinhamento das edificações eram condições necessárias, mas não suficientes, para que uma povoação recebesse uma apreciação positiva dos observadores contemporâneos: para serem julgadas "belas", as ruas deveriam ser pelo menos planas e retilíneas e, na medida do possível, com fachadas contínuas e uniformes. Mas raramente esse ideal foi atingido, o que explica o uso recorrente da palavra "irregular" nas descrições dos núcleos coloniais, bem como a preocupação expressa num interessante documento citado por Maria Fernanda Derntl. Trata-se de uma carta de Luís Antônio de Sousa Botelho Mourão, governador da capitania de São Paulo, para o ajudante de
73. Ver Cláudia Damasceno Fonseca (1998c).

74. Cf. José Joaquim da Rocha (1995, p. 105).

75. Cf.José João TeixeiraCoelho $(1994$, p. 78$)$.

76. Idem, p. 79.

77. Idem, p. 61.

78. Cf. Diogo Pereira Ribeiro de Vasconcellos (1901, p. 792). 
79. Luís Antônio de Sousa Botelho Mourão (1769), apud Maria Fernanda Derntl (2010, p. 171); grifos nossos.

80. Tomé de Souza (1553), apud Sérgio Buarque de Holanda (1991, p. 75, n. 105); grifos nossos.

81. Cf. Sylvio de Vasconcellos (1959b, p. 122).

82. Ver Cláudia Damasceno Fonseca (2003a, cap. 11)

83. Cf. Murillo Marx (1991, p. 390). ordens Afonso Botelho de Sampaio e Sousa, escrita em São Paulo no dia 19 de julho de 1769, e referente à fundação de novas povoações na Capitania de São Paulo: "remeto a vosmecê o plano de como se devem formar as quadras nas povoações, vosmecê diminuirá ou acrescentará aquilo que vir é mais conveniente, porque da forma que explico no dito plano fica logo a terra formada na sua grandeza e precavido que pelo tempo adiante não entortem as ruas como costumam"79.

Outros indícios nos levam a pensar que não se deve superestimar a capacidade das câmaras coloniais em exercer um controle efetivo sobre o espaço construído, assegurando o cumprimento dos citados preceitos de estética urbana. Note-se, em primeiro lugar, que em alguns casos a forma urbana "espalhada" e irregular do arraial primitivo já havia se cristalizado em construções em pedra e cal, que não se podiam demolir facilmente. Este fato certamente se produziv em Vila Rica e foi observado em outras regiões da colônia. As vilas de Santos e de São Vicente parecem ter constituído as primeiras ocorrências deste problema, segundo uma carta que Tomé de Souza enviou ao rei, citada por Sérgio Buarque de Holanda: "estas duas vilas [... não estão cercadas, e as casas de tal maneira espalhadas que se não podem cercar senão com muito trabalho e perda dos moradores, porque tem casas de pedra e cal e grandes quintais e tudo feito em desordem"80. Havia, ainda, o fato de poderem ser as determinações camarárias pura e simplesmente desprezadas pelos moradores. Em 1959, Sylvio de Vasconcellos lembrava que:

São muito frequentes em cartas régias, em acórdãos da câmara e em despachos da Coroa, determinações por se fazerem ruas tão largas quanto possível, direitas e alinhadas por casas da mesma figura uniforme, etc. [...] acontece apenas que as recomendações não eram obedecidas senão esporadicamente ou apenas em parte, conforme as permitiam as condições locais, ou as impunha, com maior ou menor intensidade, a administração local ou rea ${ }^{81}$.

Ora, no que toca à "administração local" a ação reguladora da câmara também era limitada pelos interesses de pessoas e de grupos sociais influentes - que incluíam membros da própria câmara ${ }^{82}$. Lembre-se, enfim llast but not least), um outro aspecto, que talvez seja o mais essencial para entender o processo de desenvolvimento das povoações. Como observou Murillo Marx, os "ranchos", as casas e capelas dos arraiais mineiros não "brotavam" em terra de ninguém, mas eram erguidos sobre terrenos que tinham algum tipo de estatuto fundiário - datas minerais, patrimônios religiosos, sesmarias ${ }^{83}$. Assim, se a gênese e o crescimento de grande parte dos arraiais mineiros podem ser classificados como "espontâneos" - na medida em que as iniciativas partiam de particulares e que não havia um plano pré-definido pelas autoridades metropolitanas ou coloniais -, tais processos não eram, no entanto, "aleatórios", como bem notou Nestor Goulart. Além das eventuais "formas de condicionamento" antes referidas, os moradores eram obrigados a levar em conta um importante fator: a "propriedade" ou a "posse" da terra onde pretendiam erguer seus "ranchos" e capelas. Com a 
criação da vila e da câmara, a questão se tornava ainda mais complexa, pois surgia uma terceira tipologia fundiária: as "terras do concelho", comumente referida como "rossio" ou "sesmaria da câmara" na documentação mineira ${ }^{84}$.

Neste aspecto, o caso de Mariana é bastante eloquente. Se as transformações mais visíveis só ocorreriam depois de 1745, data da criação da diocese, é certo que, logo nos primeiros anos da vila do Carmo, o poder municipal procurou legislar sobre o espaço urbano. No entanto, em 1711, quando a vila fora instituída, os oficiais esbarraram num grave problema: o rossio - ou seja, a "sesmaria" atribuída pela Coroa à câmara - sobrepunha-se a concessões mais antigas. A maior parte dos terrenos da vila estava na posse dos "primeiros moradores" (isto é, dos que ali chegaram antes de 1711), e estes mineiros logo demonstraram que não pretendiam reconhecer o "direito de senhorio" da câmara sobre suas terras. Nisto foram apoiados pelo governador D. Bras Baltazar, que considerava que, "sem prejuízo de terceiros, pois junto desta vila há muitos sítios por muito cabedal", as terras da câmara deveriam ser demarcadas. $\bigcirc$ conflito durou várias décadas: os primeiros protestos enviados à Lisboa pelos moradores "antigos" da Vila do Carmo ocorreram em 1716, e em 1755, a questão ainda não havia sido solucionada ${ }^{85}$. E claro está que, se a população não reconhecia a legitimidade da câmara para cobrar foros de seus chãos e casas, certamente também não se submetia facilmente às regras de urbanismo. A confirmação régia da concessão da "sesmaria da câmara", em 1719, e a demarcação física dos seus limites (colocação de balizas ou "marcos" de madeira), não bastou, com efeito, para resolver a questão. A repetição de editais de mesmo teor atesta a pouca obediência dos moradores aos regulamentos camarários que visavam ordenar a ocupação dos terrenos e conferir maior regularidade aos arruamentos:

Porquanto nos consta que muitas pessoas e moradores desta vila costumam reedificar casas metendo-the esteios e baldrames novos, fazer valos, cercas e paredes sem para isso serem primeiro arruadas, e sem faculdade deste Senado, como também levantarem casas sem darem parte, mandamos que daqui em diante nenhuma das sobreditas pessoas possa reedificar as ditas casas nem também levantá-las, nem cercar nem valar, estando dentro da demarcação da sesmaria deste Senado, sem que se faça saber ao mesmo Senado para se lhe aforar, com pena de se the demolir a dita obra ${ }^{86}$.

Os problemas resultantes da proximidade - ou mesmo da superposição - entre datas minerais e moradias também dificultaram o controle dos aforamentos, a regularização dos arruamentos e a regulamentação das construções. Foi o que aconteceu no arraial de cima de Mariana (em torno da capela de São Gonçalo), onde ainda havia lavras de ouro abertas no início da década de 1750. A câmara também teve de lidar com a resistência de moradores atingidos pelas enchentes do ribeirão, que, por ordem da Provedoria da Fazenda, haviam reconstruído suas casas no terreno previsto para os novos arruamentos ${ }^{87}$.
84. Ver Cláudia Damasceno Fonseca (2003a).

85. Idem, cap.10-11.

86. Cf. Arquivo Público Mineiro, CMM, códice 3,fl.125v

87. Ver Cláudia Damasceno Fonseca (1998b). 
88. Cf. Arquivo Histórico da Câmara de Mariana, ICHSUFOP, códice 462 , f. $65 \mathrm{v}$.

89. Ibidem.

90. Idem, f. 93v.
Em novembro de 1748, quando o primeiro bispo D. Manuel da Cruz fez sua entrada triunfal na cidade, o décor da "parte nova" estava longe de ser concluído. As procissões solenes tiveram que ser organizadas de maneira a evitar as novas ruas e travessas, pois, conforme indica a documentação coeva, tais quadras estavam ainda pouco preenchidas com edifícios, devido a um processo especulativo. Com efeito, um edital publicado pela câmara em 6 de agosto de 1750 faz menção ao comércio ilícito dos terrenos de Mariana, feito principalmente por pessoas de "poucos cabedais", que não tinham condições de construir nos chãos que pediam, sendo seu único intento "apossarem-se dos terrenos para vendê-los" 88 . O Senado decidia que, daí em diante, os foreiros teriam um prazo de dois meses para construir suas casas, ficando proibida a venda de terrenos. E porque "alguns foreiros apenas levantam as frontarias das casas, e fazem qualquer outra pequena obra dispensando nesta pouco custo para assim venderem os chãos", ficava determinado que somente seria autorizado o comércio de "casas inteiramente feitas e levantadas". No mesmo edital, os camaristas procuravam garantir o cumprimento da exigência régia relativa à forma de implantação das casas (e quintais) sobre os lotes; no entanto, dadas as dificuldades de conseguir impô-la à população, tiveram que se mostrar maleáveis, propondo soluções alternativas - e bastante criativas - para os espaços já construídos fora das normas determinadas pelo rei. Uma das exigências visava garantir, no interior do núcleo urbano, uma certa continuidade no arruamento e no ritmo de cheios e vazados das "frontarias" das casas.

Mandamos, conforme ordem de Sua Majestade, que para maior formosura das ruas, todas as casas que se fizerem nesta cidade para dentro das três pontes públicas não terão paredes de quintais correspondentes às ruas e travessas, e quando pela sua situação não possam deixar de as ter, as mesmas se fabricarão de sorte ornadas de janelas, portas e beiradas, que pareçam frontarias de casas, pena de se demolirem à custa dos senhores das mesmas, e de ser obrigados da Cadeia a edificá-las da forma do sobredito, e isto mesmo se observara no termo de dois meses a respeito de todas as mais casas que se acham já feitas com a sobredita desordem, sitas no mesmo distrito, debaixo da cominação das referidas penas ${ }^{89}$.

É interessante notar que este edital só dizia respeito a uma parte restrita da cidade, delimitada pelo Ribeirão do Carmo e pelos córregos do Catete e do Seminário - o que corresponde, grosso modo, ao que chamamos hoje de "centro histórico". Após a realização do tombo do rossio e das medições dos terrenos pelo ouvidor Costa Matoso (a partir de fevereiro de 1752), os oficiais tentaram impor regras de alinhamento também aos habitantes dos arrabaldes e das "estradas públicas" que os ligavam à parte central da cidade, uma vez que tais terrenos estavam incluídos na "sesmaria da câmara" que fora demarcada pelo magistrado com toda a precisão possíve ${ }^{90}$. Aparentemente, os "marcos" (balizas) que foram então plantados nos quatro cantos do terreno assinalavam não apenas o perímetro do rossio, mas também os limites da autoridade municipal em matéria de urbanismo: 
Fazemos saber a todos os moradores da Cidade e seus Arrabaldes que têm casas dentro da sesmaria do Senado, que não metam esteios na frontaria de suas casas, nem abram janelas, e portas, nem ainda nas paredes dos quintais façam obra alguma, sem estar presente o Escrivão deste Senado e o arruador, com pena de serem presos e pagarem a condenação que the arbitrarmos ${ }^{91}$.

Esses dados empíricos colocam em evidência a importância da análise das questões fundiárias para um melhor entendimento dos processos de gênese das povoações coloniais e das possibilidades reais de controle da forma urbana pelas autoridades locais. Cabe aqui lembrar a importante contribuição dos saudosos Murillo Marx e Maurício Abreu. Vários dos textos ensaísticos do primeiro procuraram chamar a atenção dos estudiosos para este aspecto, que, aliás, não havia sido ignorado pelos precursores da geografia histórica e da história da urbanização brasileira: Pierre Deffontaines e Pierre Monbeig, em trabalhos anteriormente citados $^{92}$. Entre os geógrafos brasileiros, Maurício Abreu foi um dos que mais se dedicou a este tipo de estudo, e sua pesquisa monumental sobre o Rio de Janeiro, recém-publicada, constituirá sem dúvida uma obra de referência. Esta cidade reúne, aliás, boa parte dos estudos existentes sobre a posse da terra urbana no Brasil colonial, como os de Fania Fridman (outra pioneira da história fundiária) e de Maria Fernanda Bicalho, bem como o livro de Nireu Cavalcanti, que também apresenta dados interessantes sobre os terrenos municipais ${ }^{93}$. Beatriz Picolloto Siqueira tem se dedicado à análise da evolução do parcelamento e do parque imobiliário da cidade de São Paulo, mas basicamente no século XIX, já que os dados cadastrais do período colonial são escassos ${ }^{94}$. Neste aspecto, os estudiosos da urbanização mineira podem se considerar privilegiados: a documentação sobre os "patrimônios religiosos" dos arraiais - utilizada num estudo recente de Sérgio da Mata ${ }^{95}$ - e sobre as terras do rossio (terrenos aforados pelas câmaras) das vilas é bastante volumosa. Se tratadas com a minúcia e com os métodos adequados, tais fontes terão muito a revelar sobre os processos e os agentes da construção do urbano em situação colonial.

Outra questão essencial que começa a ser tratada pelos historiadores é a relação entre o poder político, os poderes financeiros e o urbanismo (no sentido amplo) praticado nas povoações coloniais ${ }^{96}$. Qual o volume de recursos disponíveis para aplicar em obras públicas? Como a câmara obtinha a mão de obra necessária? Quais eram os núcleos urbanos que se beneficiavam das obras realizadas com os impostos que eram coletados em todo o termo? Este último aspecto é particularmente importante: a organização municipal portuguesa, ao ser transferida para uma colônia de dimensões continentais, produziu um modelo de "cidade" que, mais do que em outras realidades geográficas, era indissociável do território por ela controlado. Aliás, as representações coevas nem sempre distinguiam claramente as vilas dos seus termos; esta fusão ou amálgama entre a "cidade" e o seu território (urbs e civitas) reflete-se, por exemplo, nos dados concernentes ao aspecto demográfico e econômico das localidades. A maior parte deles diz respeito a espaços muito mais amplos do que aqueles ocupados
91. Idem, ibidem; grifos nossos.

92. Ver Murillo Marx (1991, 1992).

93. Ver Maurício de Abreu (1997, 2010); Fania Fridman (1999); Maria Fernanda Baptista Bicalho (2003); Nireu Cavalcanti (2003).

94. Ver Beatriz Piccolotto Siqueira Bueno (2005).

95. Ver Sérgio Da Mata (2002).

96. Ver, entre outros, Maria Aparecida de Menezes Borrego (1999); Cláudia Damasceno Fonseca (2003a); e Denise Tedeschi (2010). 
97. Ver Cláudia Damasceno Fonseca e Renato Pinto Venâncio (2008); e, ainda, Cláudia Damasceno Fonseca (2009).

98. Ver Cláudia Damasceno Fonseca e Renato Pinto Venâncio (2008). pelos núcleos urbanos: para o período colonial, as séries mais completas e precisas dizem respeito às comarcas, concelhos ou freguesias, tanto no que diz respeito aos totais de população (Figura 6) quanto aos dados econômicos (como as receitas municipais). Analisar os diferentes níveis de desenvolvimento das urbes mineiras na sua individualidade torna-se, assim, uma tarefa bastante difícil97.

Saint-Hilaire e outros observadores do período identificaram vários indícios de decadência nas vilas de Minas: poucas casas ocupadas, algumas delas "arruinadas", um número reduzido de lojas e vendas, igrejas mal conservadas ${ }^{98}$. No entanto, o próprio viajante percebeu que os termos de algumas dessas vilas "decaídas" apresentavam um notável dinamismo comercial e que, por vezes, os arraiais subalternos podiam suplantar a sede no que toca à população e à riqueza. Na comarca de Rio das Velhas, os arraiais de Santa Luzia e Santa Bárbara tinham uma população considerável e - de acordo com os dados disponíveis referentes à derrama - apresentavam, em meados do século XVIII, um desenvolvimento econômico comparável ou superior ao de suas sedes, Vila de

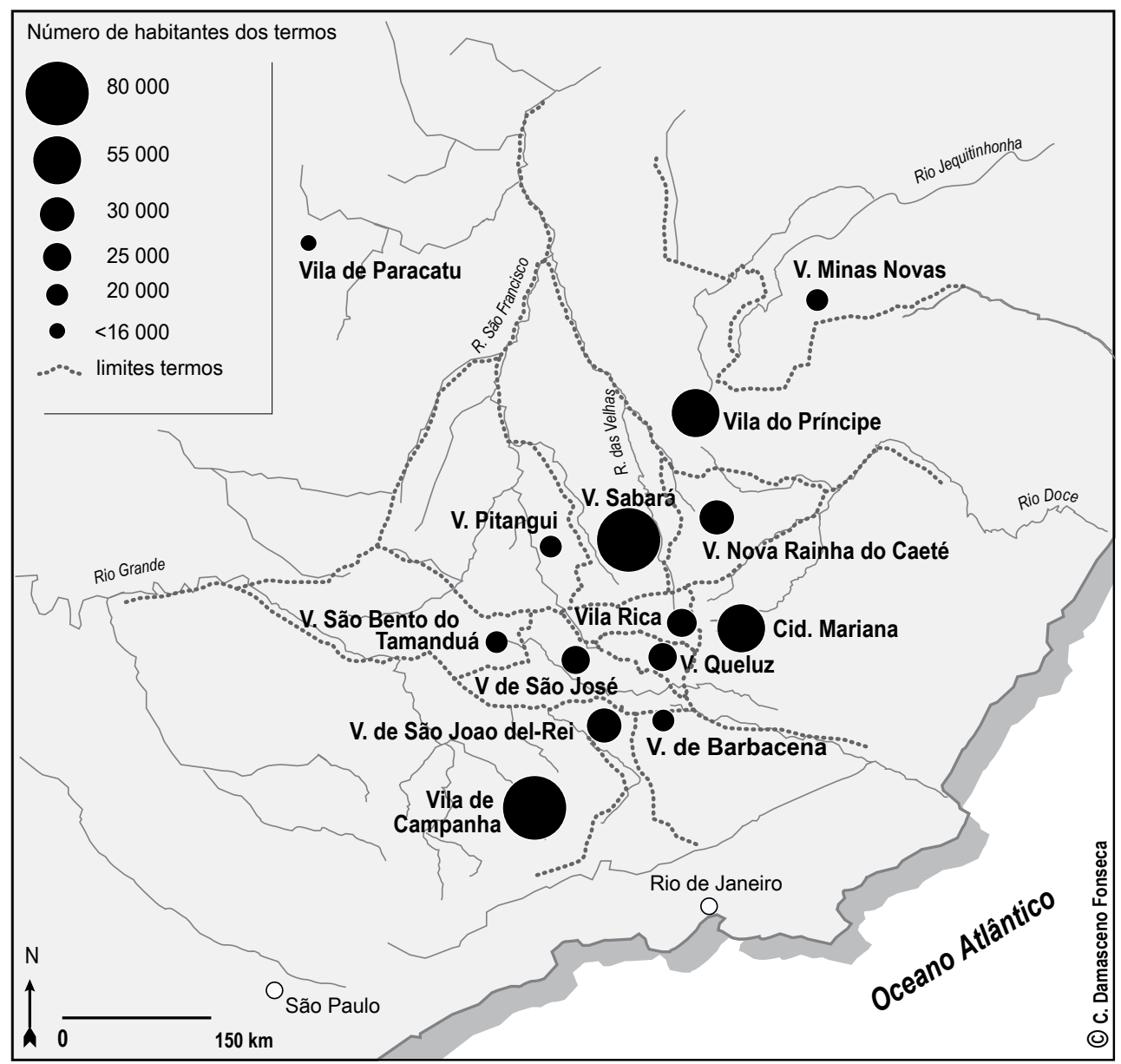

Figura 6 - População total dos termos (territórios municipais) das vilas mineiras em 1808. 
Sabará e Vila Nova da Rainha do Caeté ${ }^{9}$. Apesar disso, as duas povoações não alcançaram o título de vila durante o período colonial e, neste caso, a principal explicação reside justamente na relação de interdependência que existia entre as vilas e seus termos: as municipalidades de Minas disputaram cada arraial e cada palmo dos seus termos, e fizeram todo o possível para impedir que freguesias e arraiais fossem "desmembrados". É interessante notar, a propósito, que em algumas representações enviadas à Lisboa pelas câmaras mineiras esta relação é expressa através de uma retórica sustentada por metáforas organicistas: se uma vila (cabeça) perdia parte do seu território, o resultado poderia ser a falência de diversos "órgãos" e "membros", ou mesmo a morte do "corpo" (concelho) inteiro. Isto porque os arraiais subordinados à vila, bem como as zonas rurais circundantes não constituíam "membros inferiores" do concelho, mas órgãos vitais, que produziam boa parte das receitas municipais. Cada "desmembramento" podia, assim, ser fatal para a economia do concelho.

Tendo em vista as relações complexas que ligavam os núcleos urbanos aos espaços circundantes, conclui-se que a vila, para os contemporâneos, não era apenas a urbs - um conjunto de ruas, praças, casas e igrejas -, pois eles as associavam sempre à civitas - o território no qual todos os habitantes estavam submetidos ao poder de uma mesma câmara. A imagem resultante desta associação assemelha-se a um complexo patchwork, constituído por espaços que apresentavam diferentes estágios de organização e de "urbanidade". É importante, pois, levar em consideração essas diferentes dimensões espaciais, a fim de que o estudo das vilas e cidades coloniais possa refletir não somente a visão do historiador, mas também, em certa medida, as percepções coevas das relações entre os poderes, os espaços e os territórios urbanos.

\section{REFERÊNCIAS}

\section{Fontes manuscritas}

Arquivo Histórico da Câmara de Mariana

Códice 462, f. 65v [Posturas, Provisões, Editais]

Arquivo Público Mineiro

CMM, códice 3, fl. 125v [Edital].

SC 45 , f. $27 \mathrm{v}$ [Ordem régia de 2 de maio de 1746].

Livros, artigo e teses

ABREU, Maurício de. A apropriação do território no Brasil colonial. In: CASTRO, P. C; GOMES, R. L. Correa (Org.). Explorações geográficas: percursos no fim do século. Rio de Janeiro: Bertrand Brasil, 1997. p. 197-246.

Geografia bistórica do Rio de Janeiro. Rio de Janeiro: Prefeitura Municipal do Rio de Janeiro;Andrea Jakobson Studio, 2010. 2 v.
99. VerCláudia Damasceno Fonseca (2003a, cap. 8). 
ARAÚJO, Renata Klautau Malcher de.A fronteira a oeste: Mato Grosso. In: ROSSA, W.;ARAUJO, R.; CARITA, H. (Coord.). Actas do Colóquio Internacional Universo Urbanístico Português, 14151822. Lisboa: CNCDP, 2001. p. 887-904.

.As cidades da Amazônia no século XVIIII: Belém, Macapá, Mazagão. Porto: FAUP, 1998.

O patrimônio de origem portuguesa na América do Sul: arquitetura e urbanismo. In: MATTOSO, José (Dir.). Patrimônio de origem portuguesa no mundo. Arquitetura e urbanismo:América do Sul. Lisboa: Fundação Calouste Gulbenkian, 2010. p. 20-45.

AZEVEDO, Aroldo de. Arraiais e corrutelas. Boletim Paulista de Geografia, n. 27, p. 3-26, out. $1957 a$.

Embriões de cidades brasileiras. Boletim Paulista de Geografia, n. 25, p. 39-69, mar. 1957b.

Vilas e cidades no Brasil colonial (ensaio de geografia urbana retrospectiva). In:ASSOCIAÇÃO DE GEÓGRAFOS BRASILEIROS. Anais..., v. 9, t. 1. São Paulo: [s.n], 1957c.

BARBOSA, Waldemar de Almeida. Dicionário bistórico geográfico de Minas Gerais. Belo Horizonte: Itatiaia, 1995.

BASTOS, Rodrigo Almeida. A arte do urbanismo conveniente: o decoro na implantação de novas povoações em Minas Gerais na primeira metade do século XVIII. 2003. Dissertação (Mestrado em Arquitetura) - Escola de Arquitetura da Universidade Federal de Minas Gerais, Belo Horizonte, 2003.

BICALHO, Maria Fernanda Baptista. A cidade e o Império: o Rio de Janeiro no século XVIII. Rio de Janeiro: Civilização Brasileira, 2003.

BORREGO, Maria Aparecida de Menezes. Códigos e práticas: o processo de constituição urbana em Vila Rica colonial (1702-1748). 1999. Dissertação (Mestrado em História Social) - Faculdade de Filosofia, Letras e Ciências Humanas da Universidade de São Paulo, São Paulo, 1999.

BOSCHI, Caio. Os leigos e o poder: irmandades leigas e política colonizadora em Minas Gerais. São Paulo: Ática, 1986.

Achegas à história de Minas Gerais (séc. XVIII). Porto: Universidade Portucalense, 1994a.

Colonialismo, poder e urbanização no Brasil setecentista. In: COLÓQUIO DE ESTUDOS HISTÓRICOS BRASIL-PORTUGAL, 1. Anais... Belo Horizonte: PUC-MG, 1994b. p. 101-106.

BRENNA, Giovanna Rosso del. Medieval ou barroco? Proposta de leitura do espaço urbano colonial. Barroco, Belo Horizonte, n. 12, p. 141-145, 1982.

BUENO, Beatriz Piccolotto Siqueira. Desenbo e desígnio: o Brasil dos engenheiros militares (15001822). 2001. Tese (Doutorado em Arquitetura e Urbanismo) - Faculdade de Arquitetura e Urbanismo da Universidade de São Paulo, São Paulo, 2001.

Tecido urbano e mercado imobiliário em São Paulo: metodologia de estudo com base na Décima Urbana de 1809. Anais do Museu Paulista, São Paulo, v. 13, n. 1, p. 59-97, jan.-jun. 2005.

CARTA de Dom Lourenço de Almeida, 18 de abril de 1722. Revista do Arquivo Público Mineiro, v. 31, p. 113-114, 1980. 
CAVALCANTI, Nireu. O Rio de Janeiro setecentista. Rio de Janeiro: Jorge Zahar, 2004.

CHICÓ, Mário. A "cidade ideal" do Renascimento e as cidades portuguesas da India. Separata de: Garcia de Horta: Revista da Junta das Missões Geográficas e de Investigação do Ultramar, Lisboa, n. esp., p. 319-328, 1956.

CHRYSOSTOMO, Maria Isabel. Política administrativa e formação das vilas e cidades na província do Rio de Janeiro. In: COLÓQUIO INTERNACIONAL CORTES, CIDADES, MEMÓRIAS: Trânsitos e transformações na modernidade. Anais... Belo Horizonte, Centro de Estudos Mineiros-UFMG, 2010, p. 91-115.

COELHO, José João Teixeira. Instrução para o Governo da Capitania de Minas Gerais [ca. 1780]. Belo Horizonte: Fundação João Pinheiro, 1994.

COSTA, Antônio Gilberto (Org.). Cartografia da conquista do território das Minas. Belo Horizonte: Editora UFMG; Lisboa: Kapa, 2004.

DA MATA, Sérgio. Chão de Deus: catolicismo popular, espaço e proto-urbanização em Minas Gerais, Brasil; séculos XVIII-XIX. Berlim:WVB, 2002.

DEFFONTAINES, Pierre.The Origin and Growth of the Brazilian Network of Towns. Geographical Review, v. 28, n. 3, p. 379-393, jul. 1938.

DELSON, Roberta Marx. New towns for Colonial Brazil. Syracuse: Syracuse University, 1979.

DERNTL Maria Fernanda. Método e arte. Criação urbana e organização territorial na capitania de São Paulo, 1765-1811. 2010. Dissertação (Mestrado em Arquitetura e Urbanismo) - Faculdade de Arquitetura e Urbanismo da Universidade de São Paulo, São Paulo, 2010.

DIÁRIO da jornada que fez o exmo. D. Pedro desde o Rio de Janeiro até a cidade de São Paulo e desta até as Minas, no ano de 1717. Revista do SPHAN, n. 3, p. 295-316, 1939.

FONSECA, Cláudia Damasceno. Mariana: gênese e transformação de uma paisagem cultural. 1995. Dissertação (Mestrado em Geografia Humana) - Instituto de Geociências da Universidade Federal de Minas Gerais, Belo Horizonte, 1995.

O espaço urbano de Mariana: sua formação e suas representações. In: IHCS-UFOP (Org.). Termo de Mariana: história e documentação. Ouro Preto: Editora da UFOP, 1998a, p. 27-66.

Do arraial à cidade: a trajectória de Mariana no contexto do urbanismo colonial português. In: CARITA, Helder;ARAÚJO, Renata (Coord.). Colectânea de Estudos Universo Urbanístico Português 1415-1822. Lisboa: CNCDP, 1998b. p. 267-301.

. Funcionários régios, eruditos locais, viajantes estrangeiros: representações da cidade colonial mineira. In: SALGADO, I. (Org.). Anais Eletrônicos do V Seminário de História da Cidade e do Urbanismo. Campinas:ARM, 1998c.

Contextos e agentes das intervenções urbanísticas nas Minas Gerais do século XVIII. Oceanos: a construção do Brasil urbano, Lisboa, n. 41, p. 84-102, abr. 2000 [CNCDP].

Pouvoirs, villes et territoires. Genèse et représentations des espaces urbains dans le Minas Gerais (Brésil), XVIII'-début du XIX ${ }^{\mathrm{e}}$ siècle. 2001. Tese (Doutorado em História) - École des Hautes Études en Sciences Sociales, Paris, 2001. 
Des terres au villes de l'or. Pouvoirs et territoires urbains au Minas Gerais (Brésil, XVIII ${ }^{\mathrm{e}}$ siècle). Paris: Centre Culturel Calouste Gulbenkian, 2003a.

Funções, hierarquias e privilégios urbanos: a concessão dos títulos de vila e cidade na capitania de Minas Gerais. Varia Historia, Belo Horizonte, n. 29, p. 39-51, jan. 2003b [FAFICHUFMG].

Irregulares ou pitorescas? Olhares sobre as paisagens urbanas mineiras. In: FURTADO, Júnia (Org.). Sons, formas, cores e movimentos na modernidade atlântica: Europa,Américas e África. São Paulo:Annablume, 2008. pp. 303-318.

Comment mesurer les écarts entre les degrés d'urbanité et les titres urbains? Le cas des villes coloniales portugaises du Minas Gerais (Brésil, XVIII ${ }^{-}$-début du XIX ${ }^{\mathrm{e}}$ siècle). Histoire et mesure: mesurer la ville, v. 24, n. 2, p. 109-146, 2009.

Arraiais e vilas d'El Rei. Espaço e poder nas Minas setecentistas. Belo Horizonte: Editora da UFMG, 2011.730 p.).

; VENÂNCIO, Renato Pinto. Vila Rica: prospérité et déclin urbain dans le Minas Gerais (XVIII ${ }^{\mathrm{e}}-\mathrm{XX}^{\mathrm{e}}$ siècles). In:VIDAL, Laurent (Dir). La ville au Brésil (XVIII ${ }^{e}-X X^{e}$ siècles): naissances, renaissance. Paris: Indes Savantes, 2008. p. 179-204.

FRIDMAN, Fania. Donos do Rio em nome do rei: uma história fundiária do Rio de Janeiro. Rio de Janeiro: Jorge Zahar, 1999.

FURTADO, João Pinto. O manto de Penélope. História, mito e memória da Inconfidência Mineira de 1788-1789. São Paulo: Cia das Letras, 2002.

HESPANHA, Antonio Manuel; SILVA, Ana Cristina Nogueira da. O quadro espacial. In: MATTOSO, José (dir.). História de Portugal, 4. Lisboa: Estampa, 1993.

HOLANDA, Sérgio Buarque de. Raízes do Brasil. 23. ed. Rio de Janeiro:José Olympio, 1991.

IGLÉSIAS, Francisco. Minas Gerais. In: HOLANDA, Sérgio Buarque de (Dir.). História geral da civilização brasileira, 2. Rio de Janeiro: José Olympio, 1960. p. 364-382.

LEPETIT, Bernard. Pouvoir municipal et urbanisme (1650-1750): sources et problématique. In: LIVET, G.; VOGLER, B. Pouvoir, ville et société en Europe 1650-1750. Actes du Colloque International du CNRS. Paris: CNRS, 1981. p. 35-49.

Les villes dans la France moderne (1740-1840). Paris:Albin Michel, 1988.

MARX, Murillo. Cidade no Brasil: terra de quem? São Paulo: Edusp; Nobel, 1991. 393, 1992.

Arraiais mineiros: relendo Sylvio de Vasconcellos. Barroco, Belo Horizonte, n. 15, p. 389-

MASSENA, Nestor. Barbacena: a terra e o bomem. Belo Horizonte: Imprensa Oficial, 1985, $2 \mathrm{v}$.

MONBEIG, Pierre. Pionniers et planteurs de São Paulo. Paris:Armand Colin, 1951.

MORAES, Fernanda Borges de. A rede urbana das Minas coloniais: esgarçamentos e novas urdiduras no tempo e no espaço. In: COLÓQUIO CORTES, CIDADES, MEMÓRIAS: Trânsitos e transfor- 
mações na modernidade. Anais... Belo Horizonte, Centro de Estudos Mineiros-UFMG, 2010, p. 116-150.

OLIVEIRA, Myriam Ribeiro de Andrade. O Rococó religioso no Brasil e seus antecedentes europeus. São Paulo: Cosac \& Naify, 2003.

REIS FILHO, Nestor Goulart. Evolução urbana do Brasil. São Paulo: Edusp, 1968.

Imagens de vilas e cidades do Brasil colonial. São Paulo: Edusp; Imprensa Oficial do Estado; Fapesp, 2000.

ROCHA, José Joaquim da. Geografia histórica da capitania de Minas Gerais [ca. 1783]. Belo Horizonte: Fundação João Pinheiro, 1995.

RODRIGUES, José Honório (Org.). Consultas do Conselbo Ultramarino, 1687-1710, 93. Rio de Janeiro: Biblioteca Nacional, 1951 (Série Documentos Históricos).

RONCAYOLO, M. et al. Les miroirs de la ville: un débat sur les discours des anciens géographes. Urbi, n. 2, p. CVII-CXVIII, 1979.

RONCAYOLO, Marcel; PACQUOT,Thierry. Villes et civilisation urbaine XVIII ${ }^{e}$-XIX ${ }^{e}$ siècles. Textes essentiels. Paris: Larousse, 1992.

ROSSA, Walter. O urbanismo regulado e as primeiras cidades coloniais portuguesas. CARITA, Helder;ARAÚJO, Renata (Coord.). Universo Urbanístico Português 1415-1822: colectânea de estudos. Lisboa: CNCDP, 1998. p. 507-536.

SANTOS, Paulo. Formação de cidades no Brasil colonial. In: Separata de COLÓQUIO INTERNACIONAL DE ESTUDOS LUSO-BRASILEIROS, 5. Actas... Universidade de Coimbra, 1968. [SANTOS, Paulo. Formação de cidades no Brasil colonial. Rio de Janeiro: Editora UFRJ, 2001].

Subsídios para o estudo da arquitetura religiosa em Ouro Preto. Rio de Janeiro: Kosmos, 1951.

SILVEIRA, Luís. Ensaio de iconografia das cidades portuguesas do ultramar Lisboa: Ministério do Ultramar. $4 \mathrm{v}$.

SOUZA, Laura de Mello e; BICALHO, Maria Fernanda. 1680-1720: o Império deste mundo. São Paulo: Companhia das Letras, 2000.

TEDESCHI, Denise. A administração das rendas municipais: os contratos de obras públicas e a configuração do espaço urbano de Mariana (1745-1800). In: FERNANDES, Luciano de Oliveira (Org.). Caderno de resumos e programa do Seminário Internacional Justiça, Administração e Luta Social: dimensões do poder em Minas, 22-24 set. 2010, UFOP, Mariana. p. 27 Disponível em: $<$ http://www.seminariojals.ufop.br/cadernojals1.pdf $>$.

TEIXEIRA, Rubenilson Brazão. Da cidade de Deus à cidade dos bomens. A secularização do uso, da forma e da função urbana. Natal: EDUFRN, 2009.

TRINDADE, Raymundo Octavio da [Cônego]. Instituições de igrejas no bispado de Mariana. Rio de Janeiro: Ministério da Educação e Saúde, 1945 (Publicações do SPHAN, n. 13). 
VASCONCELLOS, Diogo Pereira Ribeiro de. Breve descrição geográfica, física e política da capitania de Minas Gerais (1806). Revista do Arquivo Público Mineiro, Belo Horizonte, v. 6, p. 757-853, 1901.

VASCONCELOS, Salomão de. Breviário bistórico e turístico da cidade de Mariana. Belo Horizonte: Biblioteca Mineira de Cultura, 1947.

VASCONCELLOS, Sylvio de. Vila Rica: formação e desenvolvimento. Residências. Rio de Janeiro: MEC; INL, 1956 [reedição: VASCONCELLOS, Sylvio de. Vila Rica. Formação e desenvolvimento: residências. São Paulo: Perspectiva, 1977].

.A arquitetura colonial mineira. In: SEMINÁRIO DE ESTUDOS MINEIROS, 1. Belo Horizonte: Imprensa da Universidade de Minas Gerais, 1957, p. 59-77 [Reproduzido em Barroco, Belo Horizonte, v. 10, p. 7-26, 1978-1979].

Formação das povoações de Minas Gerais. In: Arquitetura no Brasil: pintura mineira e outros temas. Belo Horizonte: Escola de Arquitetura da UFMG, 1959a. p. 1-6.

. Formação urbana do arraial do Tejuco. Revista do Patrimônio Histórico e Artístico Nacional, n. 14, p. 121-134, 1959b.

Artigo apresentado em 1/201 1. Aprovado em 12/201 1. 